\title{
Economisation of the Education System in Shrinking Regions? The Demographic Responsiveness of Education Demand and Supply at Different Levels of the Education System*
}

\author{
Walter Bartl
}

\begin{abstract}
Will foreseeable demographic change lead to savings in the education sector? This question is investigated in a retrospective perspective based on data from Saxony-Anhalt, the German state with the largest population decline since reunification. Results show that we can observe economisation strategies in the face of lower cohort sizes in most subsectors of the education system. These strategies are, however, not always (directly) attributable to demographic decline. Moreover, there is considerable variation in the demographic responsiveness of education demand and supply. Important intervening factors in this respect are several dimensions of educational governance and the economic conditions in a given region.
\end{abstract}

Keywords: Demographic decline - Education migration · Education planning • Demographic responsiveness $\cdot$ Economisation $\cdot$ Commodification

\section{Introduction}

Demographic change is usually perceived as a challenge for modern societies because inherited social structures tend to become inadequate for populations changing significantly in size or age composition. Almost all developed countries face ageing populations and many European and Asian countries are seeing declining populations as well. These population trends are expected to raise public expenditure for pensions, health, and care whereas demand for education expenditure and unemployment benefits might decline (European Commission/Economic Policy Committee 2009: 26). Lower expenditure in education could contribute to offsetting higher costs in other policy fields, or funds saved could be reinvested in im-

This article has supplementary figures in an online Appendix: DOI 10.12765/CPoS-2013-20en, URL: http://www.comparativepopulationstudies.de/index.php/CPoS/article/view/130/153. 
proving the quality of educational services (CEDEFOP 2009). However, budgetary projections based on demographic data assume, first, that total enrolments decline with smaller birth cohorts and, second, that education expenditure can and will be adjusted quite flexibly to total enrolment numbers. But are these two assumptions true? How responsive are different levels of the education system to demographic decline?

Contrary to simplistic projective approaches based mainly on the mathematically accurate extrapolation of demographic trends, this article aims to shed light on the role played by the specific institutional makeup of particular levels of the education system and political decisions in response to demographic changes. Expectations of a high demographic responsiveness of educational demand make sense if certain conditions are met. Under the assumption of a comprehensive and territorially limited education system with stable participation rates, declining population numbers will lead to less demand for education services (responsiveness-of-demand hypothesis). In Germany, primary schools come closest to meeting this condition: primary schools include virtually all members of a birth cohort in a given territorial unit (except those schooled in special needs schools) as schooling is compulsory and mobility across territorial borders is rather limited since attending schools outside the respective school district is more or less restricted. Consequently, participation rates are constantly high. At other stages of the education system, additional factors such as individual participation decisions limit the influence of demographic change on enrolment. On the supply side, the education infrastructure established by the welfare state is spread out geographically in order to provide equal opportunities of education. The spatial pattern of this network is more decentralised at lower levels of the education system and more centralised at the higher levels. Education capacities at each level are geared towards certain (sub)population sizes, balancing paedagogical, political, and economic concerns to a certain degree. The spatial pattern and the overall capacity of the education system as well as its organisational structure are subject to continuous political debate. Under the assumption of political and administrative regard for economies of scale, it is hypothesised that demographic decline creates pressure to economise on oversized education infrastructures (economisation-of-supply hypothesis). Nevertheless, retrenchment strategies always have to face politically competing claims of providing equal access to the education system for all. Especially in early childhood and primary education, decentralised service provision is often regarded as a crucial feature of the quality of education services. Hence, it is an empirical question how demographically responsive demand and supply are at particular levels of the education system.

The responsiveness of the education system towards demographic decline shall be investigated on a regional scale. On this relatively small scale, demographic changes are far more pronounced than on the larger national scale. A demographically shrinking region is defined as a subnational territorial unit with declining population numbers on average over at least five years. According to this criterion, East German regions are very interesting cases for closer examination as they have lost considerable amounts of their population since reunification due to lowest-low fertility rates during the 1990s (Kohler et al. 2002; Lechner 2001) and outmigration 
mainly to West Germany (Mai 2004). Since in Germany the responsibility for legislation on education rests with the German states, the analysis concentrates on the state level rather than on some smaller scale (e.g., the county level). Furthermore, this article focuses on comparing the various levels of the education system rather than spatial differences, which is a more common and of course equally important object of research. Saxony-Anhalt is the German state with the largest population decline during the last twenty years (minus 17.3 percent from 1991 to 2010). ${ }^{1}$ The following analysis will therefore be based on official data from the Statistical Office of Saxony-Anhalt.

The paper is structured as follows. The second section will give an overview of related research on demographic change and the education system. Against this background, the particular approach pursued in the present article will be elaborated. Section three analyses descriptive statistical data on the different levels of the education system in Saxony-Anhalt and draws a comparison across the education levels analysed using bivariate regressions. The article ends with a discussion of the findings and limitations of the chosen approach.

\section{The demographic responsiveness of the education system}

\subsection{Previous research}

Although demography supplies us with teeming bookshelves of work on causes of demographic change, research on possible consequences for society or particular social fields is mostly done in other disciplines. The most extensive body of literature on the consequences of demographic change for the education system counts as economic research. In various specifications of panel regression models, it investigates changes in public education spending in response to demographic ageing. In this context, two arguments have to be distinguished: the first postulates a socalled demand effect; the second assumes a generational conflict between young and old (Preston 1984). The "demand" 2 effect arises from varying cohort sizes of the population in young age groups and the specific conditions of service production in the public sector. Due to budget restrictions on the one hand and a high amount of fixed costs for teaching staff and capital on the other, total education spending cannot be adjusted in the short term to demographically induced changes in enrolment. Hence, in situations of rising cohort sizes, the growth of total expenditure is

1 In other East German states, population decline was significantly lower: e.g., in MecklenburgWestern Pomerania minus 13.2 percent and in Thuringia minus 13.1 percent (my own calculations, based on Statistisches Bundesamt 2012).

2 Note that "demand" in the education sector is a highly complex phenomenon and follows directly from demographic cohort sizes only under very specific conditions. However, in previous research this has not been sufficiently reflected (for a discussion, see Seitz 2008). One aim of this article is to clarify some aspects of the relationship between the size of birth cohorts and educational enrolment. 
kept to a minimum, whereas during phases of declining cohort sizes expenditure per student is augmented. From this point of view, it is individually beneficial to be part of a small birth cohort. The second argument of generational conflict treats age groups as interest groups and assumes that they have political preferences for maximising their own utility. As the electorate grows older, the interests of the median voter change and politicians tend to allocate more public resources to policy areas addressing older age groups instead of education.

Empirically, the production effect of changing cohort sizes among the young is larger and somewhat more stable than the generational conflict effect of the elderly via political decision making. Apart from a few international comparisons (Schultz 1988; Busemeyer 2007), most studies are based on statistical data on school expenditures from the United States (Poterba 1997; Fernandez/Rogerson 2001; Ladd/Murray 2001; Harris et al. 2001; Figlio/Fletcher 2012), but some are also based on data from European (Borge/Ratts $\emptyset$ 1995; Baum/Seitz 2003; Grob/Wolter 2005; Borge/ Ratts $\varnothing$ 2008; Kempkes 2009; Ratts $\varnothing / S \varnothing r e n s e n ~ 2010)$ and East Asian (Ohtake/Sano 2010) countries. This is a bit surprising since Europe and East Asia are far more affected by declining population numbers than the United States is. Furthermore, only few studies include those education sectors with voluntary (instead of compulsory) participation such as early childhood (Borge/Ratts $\varnothing$ 2008; Ratts $\varnothing / S \varnothing r e n s e n$ 2010) or higher education (Oberndorfer/Steiner 2006). Overall the studies find little elasticity of total school expenditure in response to changes in the size of young age groups, signifying a robust and strong negative effect on expenditure per student. The only study that departs from this overall picture shows that total expenditure on primary schools in East Germany was adjusted considerably in response to the rapid drop in fertility rates after reunification (Kempkes 2009).

The argument claiming increasing generational conflict over public budgets is more controversial at the theoretical level (e.g., Gradstein/Kaganovich 2004) than the cohort size effect. One important argument against generational conflict (in the US) is that the elderly might also be inclined to support expenditure on education because they expect rising real estate values from good-quality schools. Empirical evidence for negative effects of a growing elderly population on education expenditure is weaker than for the demand effect. Studies from the United States found negative effects at the state level (Poterba 1997; Fernandez/Rogerson 2001) but to a lesser degree at the county or school district level (Ladd/Murray 2001; Harris et al. 2001). A study based on budgetary data of the school system in the West German states from 1975 to 1999 found only weak evidence for a redistributive conflict between the young and old (Baum/Seitz 2003). However, a study on public expenditure for higher education in the West German states between 1985 and 2002 found a negative effect of demographic ageing when a rather broad definition of the elderly population was chosen (Oberndorfer/Steiner 2006). Some studies based on survey data seem to confirm that there is a certain potential for generational conflict (Cattaneo/Wolter 2007; Busemeyer et al. 2008; Ratts $\varnothing$ /Sørensen 2010), whereas other studies do not (Clark et al. 2009). Despite the somewhat controversial evidence for generational conflict, we have to bear in mind that redistributive pressure - if it ex- 
ists - comes on top of the well-documented effect of rising costs per student from declining cohort sizes (Grob/Wolter 2005: 15).

As a conclusion from these studies, it can be said that most of them provide only weak support for expectations of considerable savings in times of declining cohort sizes (the only exception being Kempkes 2009). However, the studies also have notable limitations. First, on the demand side, they tend to focus on compulsory education while regarding demand effects resulting from education choices as a disturbance rather than as a variable to be included in the analysis. This leads to the impression of an institutionally homogeneous education system while it conceals systematic differences in inclusiveness across different levels of education. Second, on the supply side, (in)elasticity of expenditure with respect to cohort size is only rarely compared across levels of education in order to identify implicit redistribution between educational sectors (an exception being Weishaupt/Weiß 1988).

Apart from the demographic responsiveness of education spending, changes in the organisation of education in response to demographic decline have been researched so far. In this context, an important distinction has been made between personnel and infrastructure policies (Kempkes 2009). While the first type alters student/teacher ratios, the latter changes the spatial distribution of the education infrastructure. The remaining part of the literature review focuses on the demographic responsiveness of education infrastructure since the availability of such an infrastructure is likely to alter individual opportunities of access in due course. In a spatial perspective, concentration of education infrastructure, on the one hand, and maintenance of decentralised education services, on the other, are considered to be the main policy options in response to declining cohort sizes (Kramer/Nutz 2006). The feasibility of these two alternatives depends on the size distribution of organisational units, and they both have opposite consequences for this distribution. Despite sustained academic controversies about intended and unintended (economic) effects of size in educational organisations (Barker/Gump 1964; Döring 1977; Fickermann et al. 2000; Andrews et al. 2002), school district mergers and school closures have been a major phenomenon, especially during the second half of the 20th century. Between 1950 and 1980, the number of school districts declined from 83,642 to 15,987 in the United States of America (Kenny/Schmidt 1994). In Austria, 20 percent of the traditional primary schools (Volksschulen) were closed between 1964 and 1976 (Meusburger 1998: 394-398); in Germany primary schools were closed predominantly between the mid-1960s and late 1970s (Derenbach/Gatzweiler 1988: 412); in Czechoslovakia, small primary schools in rural areas decreased between 1961 and 1990 by around 70 percent, with the most dynamic phase being in the 1970s when a system of central places (in the sense of Christaller) was installed by the communist regime (Kučerová/Kučera 2012: 9-10). More recently, for example, nearly 200 schools were closed in Ontario, Canada between 1999 and 2002 (BASU 2007), and between 1994 and 2003 many primary and secondary schools were closed in East Germany (Weishaupt 2006).

Furthermore, rural areas are said to be especially prone to school closures, as their settlement structure does not allow for economies of size (Åberg-Bengtsson 2009). However, low enrolment and high unit costs are not always the main reasons 
for closure decisions. In fact, (professional) ideas guiding education policy (Kramer 1997; Frank 2011), issues of social inequality (Billger 2010) and student achievement (Engberg et al. 2012), and political resistance by the communities affected often prove to be more important than purely economic reasoning (e.g., Stinchcombe 1984; Bondi 1987, 1989; Post/Stambach 1999; Kearns 2011). Moreover, economic reasoning seems to apply differently across levels of education: high expenditure per student does not increase the probability of closure for primary schools in the US but does so for high schools (Billger 2010). Many case studies associate school closures and mergers with negative impacts on the social environment, especially in peripheral areas (Sell et al. 1997; Witten et al. 2003; Bathgate 2007; Nitta et al. 2010) when the last school is closed (Meusburger 2005). Of the 700 municipalities affected by primary school closures in East Germany between 1994 and 2003, 453 lost their last school (Weishaupt 2006: 34).

Contrary to the observed pattern of school concentration, it is worth noting that small (primary) schools seem to have been rehabilitated to some degree since the 1970s, especially in rural areas (Sher 1981; Harrison/Busher 1995; Meusburger 1998: 398; Kramer 1997; Kalaoja/Pietarinen 2009; Aberg-Bengtsson 2009; for an opposing view on this topic, see Rakhkochkine 2007). This is partially reflected in the fact that administrative minimum thresholds for school size were adapted to the smaller number of pupils in West Germany in response to the decline in fertility in the 1970s (Trotha 1981). However, compared to other countries in Europe, small primary schools with mixed age classes are not a widespread phenomenon in Germany (Fickermann et al. 1998).

Taking these studies together, concentration of education infrastructure is a widely observed phenomenon, possibly contributing to cost savings for public budgets. However, as it is politically contentious and involves a variety of determinants, no unequivocal conclusion can be drawn about the likelihood of concentration in response to demographic decline. When we reiterate the main findings from economic studies, it seems to be rather improbable that regional education systems show a high demographic responsiveness. Nevertheless, previous studies on East Germany contradict this overall picture. Against this background, the following section aims to systematise possible effects of demographic change on demand for and supply of education infrastructure while taking intervening factors into account.

\subsection{Demographic responsiveness of education demand and supply}

According to previous research, an economisation of the education system in the face of demographic decline does not seem very probable. This view is basically rooted in the traditional self-description of modern welfare states as providers of equal access to education. On the demand side, the (political) definition of new target groups might offset the impact of regional population decline on enrolment. On the supply side, providing access to education is regarded as a public good, which is politically protected by all (or most) political parties. Furthermore, education infrastructure serves as an asset in the competition among localities and regions. 
From this point of view, developing or maintaining a high supply of education infrastructure for political reasons seems to be probable even in the face of high unit costs. But is there no regard for economic reasoning in education policy?

Theoretically, the relevance of smaller birth cohorts entering the (mostly) consecutive levels of the education system over the course of their lives is highly dependent on the educational governance regime at the particular level in question. For the purpose of the present article, three dimensions of governance are relevant: inclusiveness, internal differentiation, and the degree of commodification (a brief discussion of other conceptions can be found in Windzio et al. 2005: 4-6). These dimensions are partially related to each other and might be further specified into subdimensions.

The inclusiveness of an education sector depends on the normative basis for participation in education, on the one hand, and on actual participation rates in education, on the other. The normative basis for participation in education is often symbolised by a guiding idea legitimising an institutionalised order (Lepsius 1995). The normative idea of educational inclusiveness can be formally codified, as in compulsory schooling, or become manifest informally in participation patterns in optional education programmes. Both forms of institutionalisation reflect normative expectations towards standards of welfare provision. Theoretically, educational levels requiring compulsory participation are more susceptible to declining cohort sizes than are levels with voluntary participation because the former are supposed to include all members of certain age groups. Educational levels based on voluntary participation might nevertheless come close to universal participation, in which case they are similarly sensitive to demographic change. While primary school attendance has been established as part of compulsory education in most parts of the world, especially after World War II (Meyer et al. 1992), participation in (upper) secondary education is still voluntary in many countries worldwide (World Bank 2006: 70), as is attendance of early childhood and higher education in most cases. Although true for the most part, certain countries, such as Japan, for example, have reached universal inclusion in higher education, making demand for services highly responsive to demographic decline (Yonezawa/Kim 2008; Vincent-Lancrin 2008).

Furthermore, the internal differentiation of an education sector determines if the whole sector is affected evenly by demographic decline or if some parts are more vulnerable than others. In hierarchically differentiated education sectors, the lower tiers should be more responsive to demographic decline than the higher tiers. In the latter case, growing demand for university entrance credentials can offset declining cohort sizes. In Germany, for example, primary education is the only (almost) comprehensive level of schooling, whereas the several tiers of secondary schooling are hierarchically differentiated according to the social value of the credentials particular school types offer. Moreover, a high level of horizontal differentiation (e.g., specialisation by subject) requires relatively large organisational units, more centralised service provision, and higher mobility of target groups. This is quite obvious when, for example, primary and higher education are compared. Corresponding to the age and age-related capacities of the target groups, horizontal differentiation is more pronounced in higher education than at lower levels of the education system. 
However, resulting student mobility might have an impact on the responsiveness of demand for education services to changes in the size of birth cohorts.

Having specified the responsiveness-of-demand hypothesis, we must also discuss how changes in demand could affect the provision of education and, hence, public expenditure. The assumption of a demographic responsiveness of education supply is only plausible if there is an institutionalised mechanism ensuring the adaption of education facilities to (possibly) changing demand. In this respect, the third dimension of educational governance treated here, the degree of commodification of education services, becomes relevant.

The division of labour between community, state, and market in funding education services is reflected by the degree to which education is commodified. Commodification describes a "process by which a service or item is transformed into a tradable good, where a provider of this service or good increasingly acts in a profit-oriented way" (Sackmann 2007: 157). Following this perspective, three types of education providers can be distinguished:

- decommodified public providers, acting according to ideological aims,

- not-for-profit private providers (NPOs), seeking to maintain their resource base by operating in a cost-covering manner, and

- private for-profit providers (ibid.).

Recently, with the spread of New Public Management ideas (Pollitt/Bouckaert 2011), political concern for monetary resources has become more prominent even within the decommodified public sector. Growing concern in fiscal matters among public providers and commodification are two dimensions of a more general concept of economisation (Schimank/Volkmann 2012). As education (in Germany) is mostly provided by public and not-for-profit private organisations, ideologically motivated and cost-neutral responses to demographic decline should prevail. Due to the in-kind calculation of public services (usually public goods per head [Bart/ 2011a]) during planning and evaluation processes and related funding mechanisms, demographic decline might lead to financial pressure on education services. If, in the face of demographic decline, public authorities exert financial pressure on decommodified public providers or outsource service provision to not-for-profit private entities, which have to operate in a cost-covering manner, this will nourish the economisation of education (economisation-of-supply hypothesis). However, not all units at a particular educational level are subject to the same pressure, as exposure to such pressure varies by the size of education establishments. Smaller establishments can be expected to face greater financial pressure than larger ones.

The following empirical part of this article is arranged according to the sequence in which birth cohorts enter the levels of the education system during the course of their lives. It starts with an analysis of early childhood education and care, followed by primary, secondary, and vocational school education, and finally the higher education sector. 


\section{Demographic responsiveness of the education system in Saxony- Anhalt}

The demographic responsiveness of each level of the education system is analysed based on the cohort size of the targeted age group, on the one hand, and on enrolment numbers and the number of infrastructure facilities or amount of staff employed, on the other.

\subsection{Early childhood education and care}

Early childhood education and care is the first level of the education system affected by low fertility rates. As participation at this level is voluntary in most countries, the extent of that impact varies with the rate of participation in institutional services. The provision of early childhood education and care is very well developed in East Germany due to its traditional dual-earner model from state-socialist times (Hering 2009). In the German Democratic Republic (GDR), there was universal access to childcare institutions. During the later years of the GDR, 80 percent of children younger than 3 years and 95 percent of children aged 3 to 6 were in institutional childcare (Roloff 2007: 136; lower values are reported in Hank et al. 2001). After reunification, these institutions were transferred from the central state to local selfgovernment. Despite voluntary participation, such a high saturation of the "market" makes childcare institutions highly vulnerable to demographic decline.

Assuming that children younger than 6 years are the main target group of childcare institutions, Figure 1 depicts the population sizes of this age group for the years 1991 to 2010 and numbers of children in childcare centres for the years 1994 to $2010 .{ }^{3}$ Due to missing values for the very first years of the transformation, significant changes in enrolment are not captured. The population younger than 6 years old decreased by 51 percent from 1991 to 1997 (from 192,000 to 94,000 children). After this drop, the size of this age group did not vary much anymore. On the face of it, the curve of the total number of children in childcare institutions shows quite a surprising development: from 1994 to 1998 , it follows the trend, if not the proportion, of the population decline. Thereafter, it becomes completely decoupled from the demographic development. The absolute number of children in childcare institutions even surpassed the population size of the under-6-years-olds by around 20,000 children every year. This puzzle is solved by splitting the total number of children in institutional childcare into two age groups (Fig. 1). The number of children younger than 6 years old enrolled in childcare decreased roughly proportionately to the total number of children in the respective age group in Saxony-Anhalt. This development could be expected from the initial assumption about the relevance

3 From 1994-2002 official statistics were recorded only every four years. Furthermore the statistics counted only available places, not actual children in institutions in this period. Enrolled children have been counted from 2006 onwards. The years mentioned in this article always refer to the beginning of a school year: e.g., 1991 refers to the school year 1991/92. 
Fig. 1: Population under 6 years and participation in childcare in SaxonyAnhalt (1991/1994-2010)

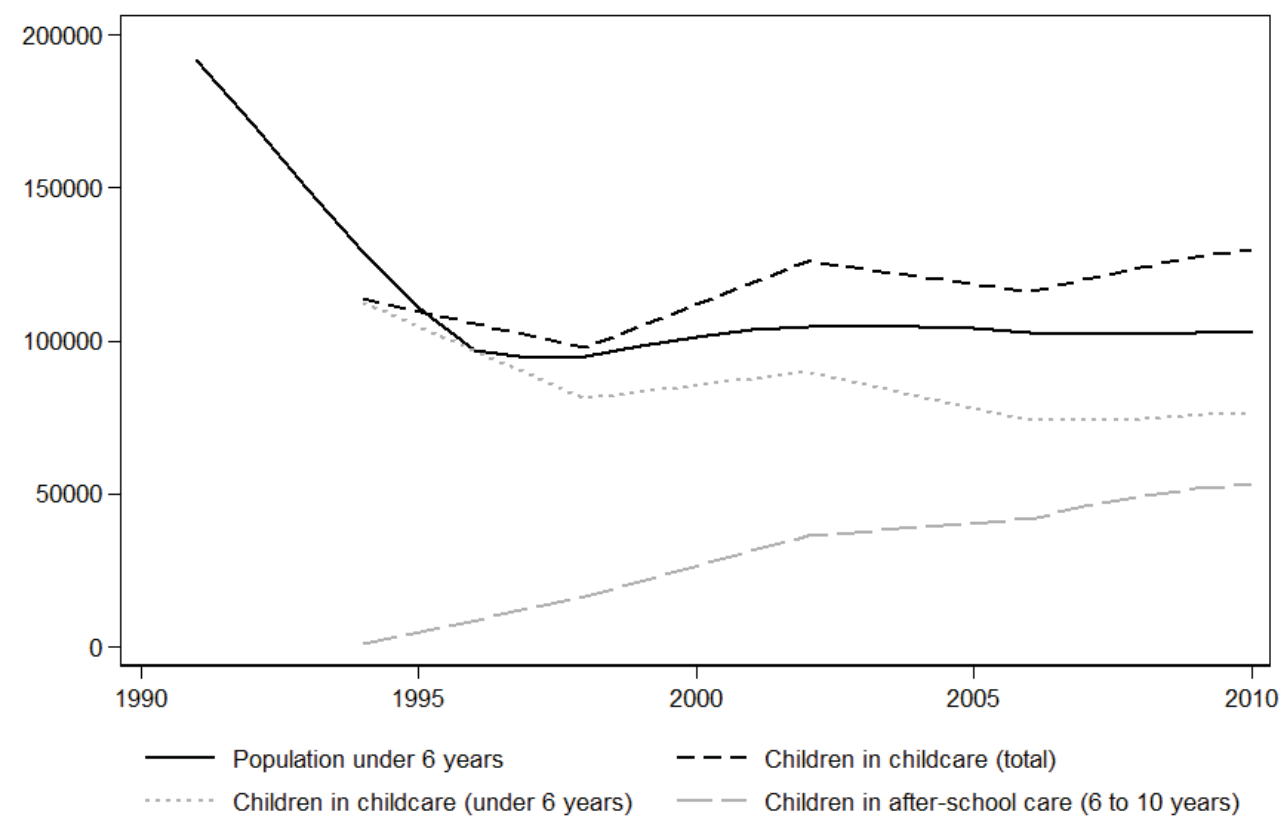

Source: Statistisches Landesamt Sachsen-Anhalt, Statistisches Bundesamt, own calculations

of institutional participation rates as intervening factors in the relationship of cohort size and absolute enrolment numbers. High participation rates in voluntary education sectors make them highly sensitive to demographic decline. While this holds true for the age group under 6 , total childcare enrolment becomes decoupled from the declining demographic trend through - at first glance somewhat surprising - additional enrolments of children in after-school care. In the period analysed, after-school care was transferred from primary schools to early childcare centres. The number of children from 6 to 10 years in after-school care increased from 1,000 in 1994 to 52,000 in 2010. With respect to the transformation years after 1994, this increase even overcompensated for the losses in the younger age group. This is quite a typical development for East Germany. Therefore the available places in 
after-school care in East Germany rose between 1990 and 2002 from 22 to 41 percent (Statistisches Bundesamt 2004: 36). ${ }^{4}$

On the supply side, the number of childcare centres in Saxony-Anhalt decreased from around 2,000 to 1,700 between 1994 and 1998 (Fig. 6 in the appendix). ${ }^{5}$ During the following years, the number of institutions remained fairly stable at about 1,700 due to the compensating demand effect of rising enrolment in after-school care. Nevertheless, the remarkable stability of the total number of childcare centres in the later period of analysis (1998-2010) ${ }^{6}$ conceals economising strategies in the early childhood education system. First, the transfer of public childcare centres to not-for-profit providers reduces public costs. NGOs do not receive full coverage of their wage bill from public funds, and employees usually earn less than in the public sector (Bart/ 2011b: 205-206). The number of public childcare centres was reduced from 1,800 to 1,000 and the number of private not-for-profit childcare centres increased from 200 to 700 between 1994 and 2010. This economising strategy becomes even more evident when relative changes are considered (Fig. 7 in the appendix). Second, the state of Saxony-Anhalt reduced the parental entitlement to childcare in terms of daily hours for the unemployed to 5 hours per day in 2003 (Landtag Sachsen-Anhalt 2004). At the local level, highly differentiated childcare units targeting quite narrow age groups (nursery, kindergarten, after-school clubs) were often reorganised into multifunctional childcare organisations for broader age groups in order to gain organisational flexibility in the face of declining demand. Due to economies of scale in childcare (Bönisch/Tagge 2012), this frequently meant the closure of small units. The number of units with fewer than 20 children (the minimum threshold for childcare centres stated by law [Landtag Sachsen-Anhalt 18 July 1996: 227]) declined from 90 to 23 between 1994 and 2002 and subsequently rose again to about 50 small childcare centres, a number that remained fairly stable for the rest of the period analysed. Moreover, from expert interviews it becomes clear that there were numerous closures of childcare centres before 1994 (Bart/ 2011b) that are not reflected in the statistical data presented here. Overall, the distribution of childcare centres across the rural-urban divide remained fairly stable: between 1994 and 2010 the share of childcare units located outside of the three urban centres of Saxony-Anhalt (Magdeburg, Halle, and Dessau-Roßlau) increased slightly from 80.8 to 82.2 percent.

4 Other authors report a more constant participation rate for after-school care of around 30 percent between 1990 and 1999 based on data from the German Socio-Economic Panel Study (SOEP). Note, however, that only small variations in the classification of age groups can lead to considerable changes in values (Hank et al. 2001: 17; 9). We can nevertheless not rule out that the observed increase in available places between 1994 and 2002 might be somewhat artificial as responsibility for after-school care originally rested with primary school providers (municipalities) and personnel was employed by the state (as in schools). The transfer of service provision to a NPO was only possible if accompanied by a transfer of public staff (Landtag Sachsen-Anhalt 31 August 1993). Such a transfer might have been a precondition for being counted statistically. However, whatever the case may be, the data from 2006 to 2010 validates the overall rising trend.

5 Data on the supply side is available from 1994 to 2010.

6 The discussion on data validity in footnote 3 might apply here as well. 
In concluding this section, it can be stated that demographic decline affects early childhood education and childcare enrolments significantly when participation rates are high. Given low participation rates, such as in West Germany or in Poland, the vulnerability of the early childhood education system to demographic change is also considerably lower (Bart/ 2011b). However, compensatory coping strategies might serve to expand the target group of institutional childcare beyond the traditional age groups. The potential for compensatory coping strategies based on recruiting children from other territorial units is very limited at this educational level. Parents commuting from a suburb to the city are the only group potentially interested in such arrangements. On the supply side, the most notable economising strategies analysed here are the closure of units and the privatisation of childcare centres from public to private not-for-profit ownership.

\subsection{Primary and secondary general schools}

The high demographic sensitivity of primary and secondary schools is rooted in the compulsory nature of participation in education. In Saxony-Anhalt the compulsory education period ends after 12 years of schooling (Landtag Sachsen-Anhalt 12 August 2005: § 40). In Germany, enrolment numbers in the school system are nevertheless not completely congruent to population numbers in the corresponding age group due to the internal differentiation of primary and secondary education and the limited inclusiveness of upper secondary education.

Congruence of enrolment numbers with the total population in the respective age group is greatest for primary schools, which theoretically educate all members of a birth cohort, except for the ones that have been attested as having special education needs. In Saxony-Anhalt these pupils are assigned to special needs schools, an institution with a strong tradition in Germany (Powell 2011). ${ }^{7}$ Hence, primary school enrolments are likely to be affected almost proportionately by demographic change.

Contrary to the internationally hegemonic model of schooling, Germany has no comprehensive school system (Wiborg 2010). After four years of schooling at the primary level, pupils transfer to secondary school. This is a selective process in that pupils are assigned to different tracks of education according to their perceived abilities. ${ }^{8}$ The traditional structure of the West German secondary school system consists of the basic-track school (Hauptschule), intermediate-track school (Realschule) and advanced-track school (Gymnasium). Instruction at a basic-track school

7 Special educational needs might be due to a diversity of reasons, which are catered to by a differentiated system of specialized schools staffed and equipped in order to provide more individualized learning than mainstream schools. The following school types for special education needs are distinguished in Saxony-Anhalt: learning difficulties, cognitive development, emotional and social development, language, hearing, visual impairment, physical development (Kultusministerium Sachsen-Anhalt 2010: 33).

8 The school system in Saxony-Anhalt - similar to the national German school system - corresponds to a regime of sponsored mobility norms in the sense of Ralph Turner (1960). 
is the academically least demanding programme and is geared towards entering vocational training upon graduation - usually after 9 years of overall schooling. The intermediate-track school has traditionally educated students who aspire to enter subordinate white-collar professions but has also become a prerequisite for the more attractive and academically more demanding programmes of vocational education and training (VET). This credential also increasingly functions as a key to alternative routes into higher education. The advanced-track school prepares students for higher education, even though not all of its graduates will proceed to tertiary education. Since the early 1970s, plans to restructure the German secondary school system have concentrated on introducing comprehensive schools (Gesamtschu(en) for all children in a given school district while offering three different credentials. These reforms became politicised, with the result that only states governed by the Social Democrats introduced comprehensive schools as one of four types of regular secondary schooling (Lehmann 1994). In East Germany, where there had been a 10 -year comprehensive school, the West German structures were creatively adapted after reunification (Sackmann 2010: 179). One innovation consisted of the creation of schools that integrate basic and intermediate tracks within a common framework. This school type is labelled differently in every state; in Saxony-Anhalt it is called the Sekundarschule. Hence, in secondary general education in SaxonyAnhalt, there is in fact a two-tier school system, including said integrated schools with two internal tracks (Sekundarschule), on the one hand, and advanced-track schools (Gymnasium), on the other. The enrolment share of comprehensive schools is marginal. Since 2011, the decision about the school career is ultimately left up to the pupils' parents. Previously, the recommendation of a certain track of secondary education issued by the primary schools was of a more binding nature for parents in Saxony-Anhalt (Füssel et al. 2010: 101). According to the ongoing trend towards greater proportions of enrolled students aspiring toward higher educational credentials, it is likely that enrolment in Sekundarschule will be more affected by demographic decline than enrolment in Gymnasium.

Figure 2 shows that at the beginning of the period analysed, the number of children aged 6 to 19 slightly increased to a maximum of 471,000 in 1995. After this peak, their number decreased continuously to 208,000 in 2009 , which amounts to a drop in the target group of general education schools by 56 percent. The demographic decline does not affect all school types in the same way and at the same time, however. The wavelike development of birth cohorts affects primary and secondary education sequentially. Primary schools, as expected, mostly followed the demographic trend and displayed proportionate changes in enrolments. With the number of enrolments dropping by 61 percent from 1991 to 2002, with a maximum of 147,000 and a minimum of 58,000 during this period, the decrease was even slightly stronger than the one observed among the age group in the total population. The integrated schools with several tracks of secondary education (Sekundarschule) recorded increasing enrolments until 1998, which then declined continuously from 151,000 to 43,000 in 2009 . With a drop in enrolment of 72 percent, they lost the largest share among the education levels and school types considered in this article. Enrolment in advanced-track schools was lower as well but by far did 
Fig. 2: Size of school-age population and enrolment in general education schools in Saxony-Anhalt

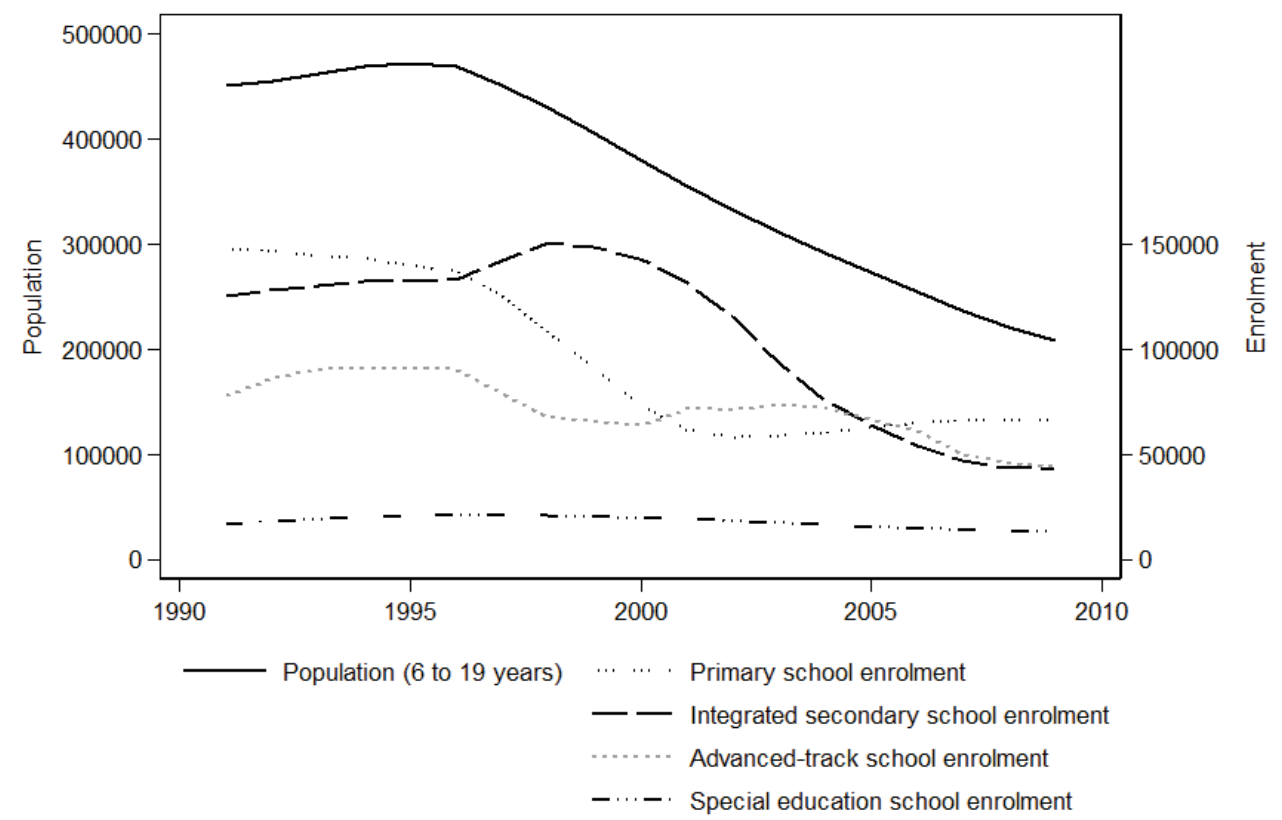

Source: Statistisches Landesamt Sachsen-Anhalt, own calculation

not nearly decline as dramatically as in the other afore-mentioned types of schools. The advanced-track schools lost 52 percent of their enrolment from an absolute maximum of 91,000 in 1994 to a minimum of 44,000 in 2009 . The number of special education enrolments decreased from 21,000 pupils, its maximum in 1997, to 13,000 in 2009, which represents a drop of 38 percent and hence a fairly stable development by comparison. This relative stability was due to an increasing participation rate in special education, which rose from 4.8 percent in 1992 to 8.6 percent in 2008 (Kultusministerium Sachsen-Anhalt 2010: 33).

The somewhat discontinuous development of enrolment in secondary schools was the product of political reforms (Kultusministerium Sachsen-Anhalt 2010: 28). First, the temporary introduction of a comprehensive orientation stage in Sekundarschule in 1997 delayed the decision on the track of secondary education a pupil is to pursue from the fourth to the sixth grade. This reform was abolished again in 2003, which benefited total enrolment numbers in Gymnasium at the expense of Sekundarschule. Second, nine instead of eight years of schooling in Gymnasium were introduced in 2001 and abolished again in 2007. The reform of the reform resulted in slightly lower total enrolment numbers in this school type.

The overall negative trend in enrolment numbers has had consequences for the provision of school infrastructure. The total number of primary and secondary schools decreased from 1,745 in 1991 to 949 in 2009, hence by minus 46 percent, 
which is only slightly lower than the decline in the targeted age group by 56 percent. Breaking these figures down by school type gives the following picture. While integrated secondary schools (Sekundarschulen) were closed at an above-average frequency (minus 70 percent), advanced-track schools (minus 44 percent), primary schools (minus 35 percent), and particularly special education schools (minus 12 percent) were able to resist the overall trend to some degree. The comparative stability of the number of special education schools is particularly striking.

Primary schools show a disproportionately low demographic responsiveness (Fig. 8 in the appendix). The number of primary schools dropped significantly during the years of rapid demographic decline (1997-2002) and continued to diminish at a lesser rate during the following years of growing population numbers in the respective age group (2002-2006) while the trend stopped thereafter. This relative stability of primary schools can be explained by a guiding idea in education policy to maintain primary schools in as many locations as possible, according to the slogan "short legs, short distances" (kurze Beine, kurze Wege), well known among German education planners. At the local level, this principle is further strengthened by the fact that schools - especially in rural areas (Haartsen/van Wissen 2012) - are seen to be part of the essential infrastructure that municipalities must provide in order to be attractive in the regional competition for residents. Contrary to common expectations about negative effects of school closures, however, there is also evidence that such concerns might be unwarranted at least in terms of triggering outmigration (Hyll/Schneider 2012). Recently, 75 public primary schools with fewer than 60 pupils (the official minimum threshold) were counted in Saxony-Anhalt (Staatskanzlei Sachsen-Anhalt February 12, 2013), indicating that rural areas have been relatively more resilient to closures than urban ones. However, plans have been announced to close these small primary schools in the years to come.

Special education schools show the lowest demographic responsiveness (Fig. 9 in the appendix). While enrolments followed a wavelike pattern of growth and decline that overcompensated for demographic decline, the number of schools remained almost constant during the period analysed: between 1991 and 2009 it decreased by only 12 percent. While special education needs admittedly had generally been growing in Germany during this period (Dietze 2011), the share of these schools in total enrolment was nevertheless particularly high compared to other German states. A possible explanation for the growing enrolment rate in this segment could be that socially selective outmigration had increased the share of pupils in Saxony-Anhalt labelled as "problematic." However, this did not lead to any particular increase in the number of pupils falling into the "softer" special needs categories (such as learning difficulties, language, and emotional and social development) intended to absorb such "problematic" pupils. Rather a quantitative shift away from the most numerous category (learning difficulties) to the less-populated categories took place, including to the more "objective" ones (visual impairment, hearing, and physical development). The share of pupils classified as having learning difficulties among all pupils with special needs, for example, was down from 72.5 percent in 1992 to 54.3 percent in 2008 (my own calculations, based on Kultusministerium Sachsen-Anhalt 2010: 33). This is a general trend in Germany (Dietze 
2011). An alternative explanation could therefore be that special schools catering to the numerically smaller categories are politically in greater need of "demand" in order to legitimise their existence, and professional discretion in the diagnostic process is used accordingly. Yet a more thorough explanation of the stability of special education demand and supply under conditions of demographic decline remains to be elaborated.

In contrast to these developments, general secondary schools were highly responsive to demographic decline (Fig. 10 in the appendix). This is probably attributable to the fact that school infrastructure undergoes a holistic planning and administration process in which the overall cost of the system is considered. In this context, general secondary schools seem to offset the relative stability of the primary and special education school infrastructure. Among the secondary schools, advanced-track schools (Gymnasien) were less responsive to demographic decline than integrated secondary schools (Sekundarschulen), which were subject to a disproportionately high number of school closures. On the one hand, the differences in the development of integrated secondary and advanced-track schools reflect the general trend towards higher school degrees in Germany and other parts of the world. On the other hand, educational reforms and numerous exceptions from the state school law stating that a Gymnasium should have at least three classes in each grade (Landtag Sachsen-Anhalt 12 August 2005) politically favoured it over the integrated secondary schools.

As an upshot of this, it can be stated that schools have slightly more time to adapt to changes in fertility rates than early childhood education and care do. Nevertheless, compulsory schooling makes general education schools highly vulnerable to demographic decline. Among the general schools, secondary schools are more affected by school closures in the face of demographic decline than primary and special education schools. Among the secondary schools, advanced-track schools are less affected by demographic decline because of educational expansion. Last but not least, these differences among school types reflect political decisions at the local and the state level in the process of adapting to demographic change. These decisions seem to take territorial cohesion into account as well. It is probably not a coincidence that the share of general schools located outside of the three urban centres in Saxony-Anhalt did not change considerably between 1991 and 2009: it rose minimally from 81.3 to 81.6 percent. However, closures of public schools also open up space for private providers: their share in school infrastructure rose from practically zero to 8.3 percent between 1991 and 2009. In 2009, their share was slightly larger in cities than in rural areas.

\subsection{Vocational schools}

Demographic change affects vocational education schools similar to general education schools because of compulsory schooling in upper secondary education. Adolescents who leave a general education school after the lower secondary grades are still obliged to attend some programme leading to an officially recognised vocational education until the age of 18 . Trainees in the dual vocational training system 
are subject to compulsory schooling until they complete VET even if they are older than 18 (Hippach-Schneider et al. 2012: 42).

The German system of vocational education is rather complicated (Thelen/Busemeyer 2012). The internationally well-known and most common type in Germany is the so-called dual system (Duales System). It is co-financed and organised by firms and the state. In this programme, instruction takes place in part-time vocational schools (Teilzeit Berufsschule) "cater[ing] to apprentices who, in addition to the practical training gained within their firms, receive both theoretical instruction in their trade and also some additional general education (...). Instruction may take place regularly for one or two days per week or, alternatively, for blocks of several weeks" (Lehmann 1994: 2475). The final certificate can be used to enter more ambitious programmes in the education system.

Another type of programme is organised at full-time vocational schools (Berufsfachschule), which are mostly state-financed but sometimes also privately (especially in the health sector). Full-time vocational schools offer professional training without apprenticeship schemes (e.g., for early childcare) or in fields with too few openings for apprentices. Similar to the dual system, the final certificate is an officially recognised professional qualification and also qualifies for admission to more ambitious education programmes.

An important third type of programme comprises different variants of the socalled transition system (Übergangssystem). ${ }^{9}$ These programmes are designed to help young people disadvantaged in the labour market to cross the first threshold from general education to vocational training. Programmes for such transition management are sometimes offered by regular public vocational schools and sometimes by private organisations receiving public funding.

A look at vocational students across all school types reveals that their average age is above the typical age of 18 , when compulsory schooling is theoretically supposed to end. In Saxony, a neighboring state of Saxony-Anhalt, the average age was, for example, 19.7 years in 2006 (Statistisches Landesamt SN 2006). Eightyfive percent of the students there were between 15 and 21 years old. This age group is therefore defined as the typical one for vocational schools in the present article. The very small birth cohorts of 1993 and 1994 in East Germany thus reached vocational education, on average, only at the end of the period under study in 2008 and 2009, and will leave it in 2014 and 2015.

Based on Figure 3, we can describe the development of the population aged 15 to 21 in four stages. After stagnation during the first two years of the period considered, their number grew during the second stage from 215,000 in 1993 to 252,000 in 1999. Subsequently, the figure decreased, initially slowly, and from 2005 on more sharply to 151,000 in 2009. The decrease between 1999 and 2009 equals minus 40 percent. In contrast, the number of vocational students declined to a far lesser degree. The number of students enrolled in vocational schools at the end of the

9 Further types of vocational schools do exist, but they comprise only a small number of students (Hippach-Schneider et al. 2012). For the sake of clarity, they are neglected here. 
Fig. 3: Population size in the relevant age group and enrolment in VET schools in Saxony-Anhalt (1992-2009)

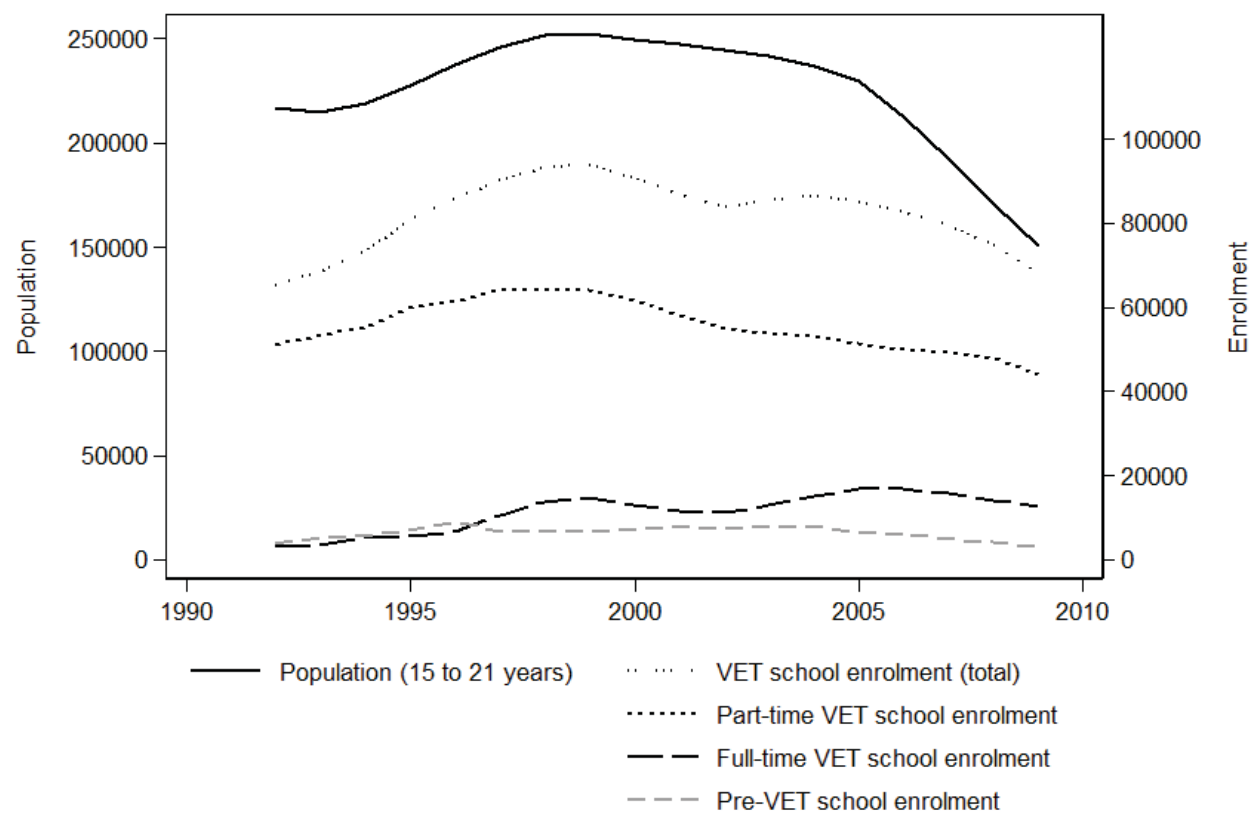

Source: Statistisches Landesamt Sachsen-Anhalt, own calculations

period analysed was almost the same as it was at the beginning of the 1990s. From less than 64,000 in 1992, the curve rises to a maximum of 89,000 in 1999 before it drops back down, in a slightly discontinuous pattern, to 63,000 in 2009 , a reduction of 29 percent. How can we explain the overall stability of vocational student numbers? The reason can be found in the development of enrolments in full-time vocational schools. Enrolment rose rapidly from only 3,000 in 1992 to almost 15,000 in 1999 and after a few years of discontinuity to a maximum of 17,000 in 2005. Then student numbers dropped to a slightly lower level again.

The relative strength of the full-time vocational schools in Saxony-Anhalt is part of the larger picture in East Germany where this branch of vocational education is more common than in West Germany (BMBF 2011: 11). In the wake of deindustrialisation and administrative downsizing in East Germany (Hannemann 2004), a lack of regular apprenticeship openings within the dual system led to bottlenecks at the first threshold from general education to labourvocational training and consequently to a postponement of vocational education within the life course of individuals (Sackmann 2000). The age of vocational students rose during the transformation process accordingly. In order to compensate for the insufficient number of vacancies in the dual VET system due to the weak economy in East Germany, state and federal authorities have agreed to expand full-time vocational schools targeting disadvantaged adolescents (Grünert 2010). A further explanation for the relative stable 
development of vocational school enrolment from 1992 to 2009 compared to the population decline in that age group is that student numbers were fairly low in the early years of the East German transformation. In 1989 the German Democratic Republic had still recorded 136,000 new apprenticeship contracts, whereas by 1991 their number had fallen to 82,000 (Grünert 2010: 240).

The development in enrolment did not leave the supply structures of vocational schools in Saxony-Anhalt unaffected. Their number dropped from 72 to 66 between 1992 and 2009. However, this apparent stability masks that the number of public vocational schools offering a high diversity of vocational programmes dwindled from 68 to 31. The fact that there was an increase in private vocational schools from 4 to 35 offset this loss only on the surface since they offer only a very restricted spectrum of vocational programmes. Hence, this shift from public to private service providers to a certain degree reflects a commodification process of vocational education. Furthermore, the spatial distribution of vocational schools also decreased significantly during this period. They became increasingly concentrated in the three largest cities in Saxony-Anhalt. Beyond the privatisation of vocational education facilities, demographic decline also catalysed further economisation strategies. During the periods of growth in enrolment, full-time vocational schools and prevocational schools expanded to a lesser degree than student numbers (Fig. 11 in the appendix), and part-time vocational schools were partially closed down in spite of temporarily rising enrolment numbers.

To conclude this section, we can hold that, theoretically, vocational education is affected by demographic decline due to VET-compulsory schooling after students leave lower secondary general education. Yet we see few signs of this constitutive vulnerability during the period considered. The process of economic and political transformation decouples enrolment in the vocational school system to a much greater extent from demographic trends than in the case of general education. A compensatory effect originates from the postponement of vocational education to a later point in the life course due to the relative scarcity of apprenticeship openings within the dual system after reunification. The targeted age group for vocational education thus broadens. In this context, the newly established full-time vocational schools in East Germany assume the traditional compensatory role of the transition system in West Germany. The structural difference in the fulfillment of this compensatory function, however, is significant. Full-time vocational schools offer officially recognised certificates of vocational education, whereas the transition system is more or less an institutional "waiting room." In spite of the factors decoupling enrolment in vocational education from demographic trends, considerable concentration processes occurred on the supply side. They are probably attributable to the fact that the highly differentiated curricula of vocational schools depend more on large organisational units in order to reach certain thresholds of minimum class sizes than general education schools do. Hence, in addition to a broadening of the targeted age group, vocational education schools partially offset demographic decline through an enlargement of their catchment areas. The commodification of vocational education increased slightly through the structural shift from public to private vocational schools. 


\subsection{Higher education}

Higher education differs significantly from the other education levels considered so far in this article because of the relatively low participation rates at the beginning of the period analysed and greater internal differentiation (between and within organisations) than any of the other levels of the education system. These differences allow for a substantial decoupling of higher education from demographic trends. In contrast to general and vocational schools, there is no obligation to participate in higher education. Furthermore, international comparisons show that Germany still has quite a low participation rate in higher education (OECD 2011: 308). Due to the very strong system of dual vocational training, this is a traditional feature of the German regime of skill formation (Nikolai/Ebner 2012). Below a certain saturation point of universal access, the participation of the regional population entitled and inclined to enter higher education should be decisive for the absolute number of enrolled students (Mayer 2008). We also need to take student mobility as a potential intervening factor into account since higher education is highly differentiated and the provision of education at this level fairly centralised compared to lower levels of the education system. The typical age group for higher education from 19 to 29 has reached a stage in life when it is (legally) possible to live on one's own. This opens up opportunities of spatial mobility to realise one's personal educational aspirations. Hence, the constituency of tertiary education institutions is theoretically less limited to their immediate regional context than that of kindergartens and schools, for example. A central prerequisite on the supply side to enlarge the catchment area of higher education organisations is attractive educational programmes and substantial academic quality.

Figure 4 reveals that the population aged 19 to 29 in Saxony-Anhalt declined continuously from 375,000 to 293,000 between 1991 and 2001; subsequently it developed more discontinuously, but the changes were on a smaller scale. The population decline in the relevant age group for higher education was 22 percent during the 1990s. By contrast, the number of students rose continuously from 22,000 to 52,000 between 1992 and 2004 - an increase of 136 percent - and then stagnated at this level in the following years. While universities and art schools doubled their enrolment during the period considered here, applied universities quadrupled their student numbers. The faster growth of (the less expensive) applied universities is a universal phenomenon in Germany (Autorengruppe Bildungsberichterstattung 2010: 121).

In the case of higher education, it becomes clear that rising participation rates contribute to a decoupling of enrolment from demographic trends. This decoupling admittedly depends on initially low participation rates. The overall expansion of enrolment in higher education in Saxony-Anhalt is partly attributable to the general process of expanding higher education observed worldwide (Schofer/Meyer 2005). The spread of ideas about the benefits of higher education leads policymakers to invest in human capital. However, the especially steep rise in enrolment in SaxonyAnhalt is also rooted in the transformation process after German reunification. Socialist states started to limit access to higher education from the late 1970s onward, 
Fig. 4: Population aged 19 to 29 and enrolment in higher education in SaxonyAnhalt (1991/1992-2010)

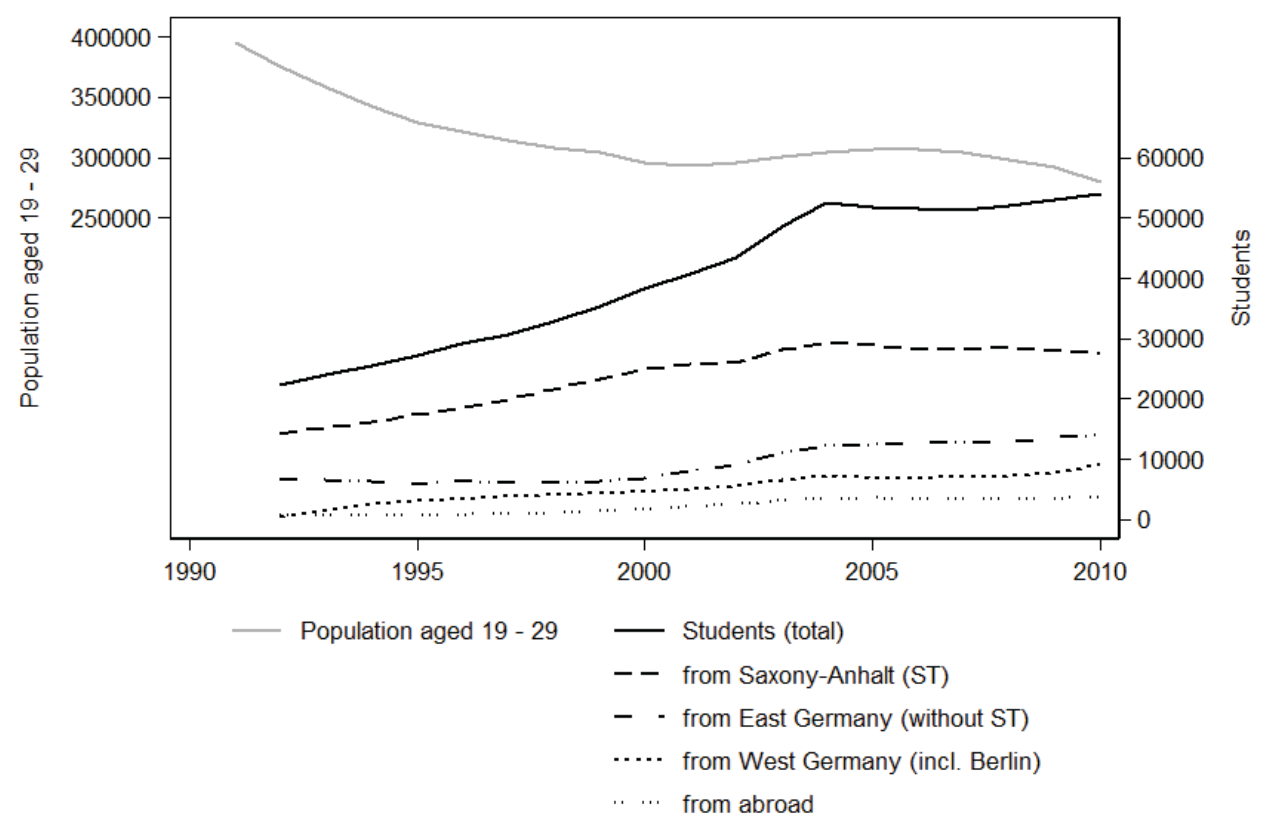

Source: Statistisches Landesamt Sachsen-Anhalt, own calculations

thereby suppressing individual aspirations to pursue tertiary education. During the transformation process, there was therefore a significant catch-up in demand for access to higher education (Baker et al. 2007; Reisz/Stock 2007), partly offsetting the effects of the prior institutional closure - at least with regard to the younger age groups.

The relative stagnation of enrolment between 2005 and 2007 was probably due to the introduction of consecutive study programmes (bachelor's and master's degree) in accordance with the Bologna process (on the latter, see Winter 2011). Enrolment numbers stagnated during the first years of reform because the new study programmes shortened the average time of study. Initially they comprised only the relatively short bachelor programmes and even later not all bachelor students proceeded to the master's level. Furthermore, with the introduction of the new programme structure, higher education institutions received more autonomy in calculating teaching capacities and determining enrolment numbers. Several political aims were to be met at the same time. The teacher/student ratio was to be improved while financial resources stagnated simultaneously - partly in anticipation of demographic decline (Witte/Stuckrad 2007: 2-3). Consequently, higher education institutions limited their enrolment numbers. After 2007, the overall number of students slightly increased again. In order to improve access to higher education in East Germany and to relieve West German universities from abundant demand, 
authorities at the federal level and the 16 German states agreed on an initiative to promote national student mobility. In the so-called Hochschulpakt 2020 (Alliance for Higher Education), which became effective in 2007, the East German states committed themselves to maintaining study capacities at the level of 2005. They received subsidies for each additional higher education entrant in exchange. The Hochschulpakt 2020 was accompanied by a marketing campaign for East German higher education institutions that attempted to motivate eligible West German students to head east. This campaign for educational migration has been remarkably successful (Gemeinsame Wissenschaftskonferenz 2012), building on a sound academic quality of higher education in East Germany. In Figure 4, this success is reflected in the growing number of students originating from outside Saxony-Anhalt.

The increase in enrolment was not accompanied by similar growth in staff between 1992 and 2009 (Fig. 12 in the appendix). Rather, the number of personnel stagnated at around 16,000 employees until 2007 and only later rose to over 17,000 (plus 10 percent). However, this relatively low increase masks the fact that the administrative staff of higher education institutions decreased significantly during the period considered. Scientific personnel increased from 5,500 persons employed in 1992 to 8,300 in 2009 (plus 50 percent). By contrast, administrative personnel were reduced by 10 percent during this time. The observed growth in academic staff was partially driven by temporary teaching contracts (Lehraufträge). Furthermore, the number of higher education institutions in Saxony-Anhalt was reduced from 16 to 12 and the number of local branches of these institutions from 21 to 17 (Bartl 2012a). In other words, the expansion of higher education places was partly enabled through an economisation of the regional higher education system in terms of staff and infrastructure.

This section allows some conclusions. Higher education is by far the level least affected by demographic change in the regional education system. This decoupling is due to the general trend of rising educational aspirations, which brings new segments of the regional population to higher education. Furthermore, higher education can count on spatial mobility much more than the educational institutions with younger participants. It is even considered a sign of high academic quality in university rankings if a higher education institution has a high ratio of students from outside the region or abroad. In the data analysed, there is no evidence for any expansion of the range of typical age groups (a potential compensation strategy to which some authors point, e.g., Vincent-Lancrin 2008).

\subsection{Comparison across the levels of the education system}

The last empirical section of this paper takes its comparative approach across different levels of the education system a step further by applying bivariate regression analysis. As the analysis is based on aggregate time series with only a limited number of observations, multivariate regression models are not viable. Both the number of education facilities and staff in higher education are regressed on changing demographic cohort sizes (Table 1). As these variables enter the regression models after logarithmic transformation, the coefficients obtained can be read 
as elasticities: they express the percentage by which the dependent variable (supply) is predicted to change if the independent variable (size of targeted age group) changes by 1 percent. Hence, the relative demographic responsiveness of supply structures can be compared numerically across different subsectors of the education system.

The regression coefficients in Table 1 bear some striking results. The first model on the responsiveness of childcare centres surprisingly reveals an elasticity of 0.64 even though total enrolment in this field was completely decoupled from demographic decline. Expressed differently, a decline in the size of the population younger than 6 years old by 1 percent is predicted to result in a decrease in the number of childcare centres by 0.64 percent - despite the compensatory effect of increasing enrolment in after-school care. Apparently, the concentration process in childcare provision is strategic so as to increase organisational flexibility and economies of scale: formerly separated units were merged and reorganised in order to form multifunctional units providing childcare and education no longer for narrow but now for broader age groups. At this level, the increasingly high level of commodification (in the sense of not-for-profit providers) could have contributed to this remarkable demographic elasticity of supply.

The next four models depict the demographic responsiveness of general schools. Compared to the high responsiveness of enrolment in primary schools, the education infrastructure in this field of education responds far less elastically to demographic decline. The number of primary schools decreases only by 0.41 percent if the population aged 6 to 10 years drops by 1 percent. This relatively low responsive-

Tab. 1: Demographic elasticity of supply of education facilities (bivariate regressions)

\begin{tabular}{rccccccc}
\hline $\begin{array}{l}\text { Population } \\
\text { age }\end{array}$ & $\begin{array}{c}\text { Childcare } \\
\text { centres }\end{array}$ & $\begin{array}{c}\text { Primary } \\
\text { schools }\end{array}$ & $\begin{array}{l}\text { Integrated Advanced- } \\
\text { secondary } \\
\text { schools }\end{array} \begin{array}{c}\text { Special } \\
\text { track } \\
\text { schools } \\
\text { education } \\
\text { schools }\end{array}$ & $\begin{array}{c}\text { Vocational } \\
\text { schools }\end{array}$ & $\begin{array}{c}\text { Staff in } \\
\text { higher } \\
\text { education }\end{array}$ \\
\hline $0-6$ & $0.64^{* * *}$ & & & & & & \\
$6-10$ & & $0.41^{* * *}$ & & & & & \\
$10-15$ & & & $1.10^{* * *}$ & & & & \\
$10-19$ & & & & $0.68^{* * *}$ & & & \\
$6-19$ & & & & & $0.13^{* * *}$ & & \\
$15-21$ & & & & & & $0.24^{* * *}$ & \\
$19-29$ & & & & & & & $-0.56^{* *}$ \\
\hline $\mathrm{N}$ & 8 & 19 & 19 & 19 & 19 & 18 & 19 \\
$\mathrm{R}^{2}$ & 0.89 & 0.82 & 0.95 & 0.92 & 0.87 & 0.28 & 0.66 \\
\hline
\end{tabular}

${ }^{*} \mathrm{p}<0.05,{ }^{* *} \mathrm{p}<0.01,{ }^{* * *} \mathrm{p}<0.001$, dependent and independent variables are logarithmised

Source: Statistisches Landesamt Sachsen-Anhalt 
ness can be attributed to the guiding idea in education planning that "short legs" should be provided with "short distances" in the education system. Integrated secondary schools show a disproportionately high demographic elasticity: a 1 percent drop in the population aged 10 to 15 years old comes with a 1.1 percent decline in the number of facilities in this field. This school type obviously is a victim of educational expansion within the framework of a hierarchically differentiated secondary school system: advanced-track schools leading to higher valued credentials display an elasticity of only 0.68 percent. Finally, special education schools are the demographically least elastic school type among general education schools. The latter seems to be due to inherited professional standards of how to deal with special education needs. Viewing general education schools as a subsystem of the regional education system, one could argue that the highly elastic general school types offset part of the fixed costs that the less elastic parts of the subsystem generate.

With an elasticity of 0.24 percent, the total number of vocational schools does not seem to respond very strongly to demographic decline. But considering only the overall number of vocational schools conceals a remarkable process of privatisation: horizontally differentiated public schools were closed while narrowly specialised private schools opened. Furthermore, there were divergent developments in different tiers of the vocational school system. The descriptive analyses showed that part-time vocational schools (and pre-vocational schools) were affected more by the demographic shrinking process than full-time vocational schools. The guiding idea behind public subsidies for full-time vocational schools was to offset the impact of the deindustrialisation process on vocational training opportunities in East Germany after reunification. However, improved labour market opportunities for young people in East Germany and the termination of public subsidies have triggered reductions in this segment of vocational education as well (Grünert et al. 2006; $B M B F$ 2011: 21).

Last but not least, the final model displayed in Table 1 suggests that staff numbers in higher education would respond negatively to demographic decline. But this is probably a spurious relationship. There is no obvious reason to believe that declining cohort sizes might contribute to rising staff numbers in higher education. More profound analyses at the micro-level of single institutions for higher education show that this relationship is statistically not significant (Bart/ 2012a). In reality, there is a positive relationship with enrolment and a negative relationship with economic development, supporting the oft-mentioned hypothesis of a third mission of higher education institutions in a regional context. As they provide public employment, higher education institutions in Saxony-Anhalt seem to be part of policies aimed at mitigating regional economic hardships. These policies attempt to meet the principle of equivalent living conditions in all parts of Germany codified in German Basic Law. In spite of this "third mission," there were significant reductions in administrative staff during the period analysed, and current discussions in SaxonyAnhalt nurture expectations of further cutbacks to come - despite rising enrolment in higher education (Ziege/e/Berthold 2013)! In this respect, Saxony-Anhalt's weak economy, partially a consequence of the transformation process (Sackmann 2010), and the anticipated termination of transformation-related public transfers in 2019 
seem to exert financial pressure on the higher education system. At this point, politicians attempt to use demography as a legitimising frame for unpopular cutbacks (Ziegele/Berthold 2013).

Overall, the seven educational fields compared in this section display an average demographic responsiveness of 0.38 . Closest to this value is the regression coefficient of primary schools. On the one hand, within the framework of hierarchical differentiation, integrated secondary schools are weakened by political decisions and individual preferences for higher levels of education. This makes them overly responsive to demographic decline. Advanced-track schools and childcare centres respond to an above-average extent to demographic decline but still not proportionally. While the concentration of childcare centres is probably driven by strategic choices on the part of municipal and private providers, closure of advanced-track schools would have been even higher if state school law were implemented literally. On the other hand, higher education institutions are the ones most independent of demographic decline. However, there have been economisation strategies at this level as well among different categories of personnel. Special education schools also prove to be relatively independent of demographic decline, especially when compared to the other general school types. This is partially due to growing participation rates in special education and the redirection of enrolment from a relatively large number of schools catering to learning difficulties to schools targeting less frequent categories of special needs education. Finally, the relative independence of vocational schools indicated in the regression coefficient is rather deceptive as it masks a process of concentration among public vocational schools that is only numerically compensated by specialised private ones.

\section{Equal access to education and economisation of infrastructure}

The education infrastructure in Saxony-Anhalt was substantially restructured during the period of analysis. Results show that the extent of demographic responsiveness of the regional education system in Saxony-Anhalt varies in and across educational levels. This variance points not only to constitutive institutional differences between educational levels but also to political discretion in coping with demographic changes. Hence, the observed variance in education infrastructure in response to demographic decline dampens simple expectations of declining expenditure in times of declining cohort sizes. At most levels, adaptation of supply was less flexible than the volatility of demographic decline and changes in enrolment. To reiterate the second assumption on the possible liberation of resources through demographic change (economisation-of-supply hypothesis), it must be said that this is only partly the case. Additionally, it is well known that school closures often externalise costs to other public realms such as school transportation (Frank 2011). More detailed data (e.g., including data on the size distribution of education establishments) probably would have revealed even more variance in the economisation of supply. Usually decisions about the closure (or not) of schools and childcare centres are made based on certain administrative thresholds. The variability in the demographic re- 
sponsiveness of supply across educational levels points towards the normative nature of political decision making on education infrastructure: cost reductions have to be weighed against the pretension of welfare states to provide (territorially) equal access to education. All the more striking is that there are economisation processes that cannot be attributed directly to demographic decline, such as in those cases with growing enrolment numbers (early childhood and higher education). Theoretically, it is possible that demographic decline exerts an indirect financial pressure on public budgets for education services. Financial scarcity in East Germany, however, results not from demographic decline in the first place but from the monetary union with West Germany and deindustrialisation during the transformation process (Sackmann 2010).

Hence, the intervening variables proposed above based on theoretical considerations (inclusiveness, internal differentiation, and commodification) have to be reconsidered with respect to results from other studies. Inclusiveness: While in Saxony-Anhalt the number of childcare centres was vulnerable to demographic decline because of a high participation rate, participation in childcare was significantly lower in Poland and West Germany (Bart/ 2011b). Participation rates can be interpreted as informal expressions of normative expectations about standards of welfare services. Hence, despite low participation rates, the familialistic welfare regime in Poland, emphasising the role of the family in childcare, made it normatively easier for municipalities to close existing childcare centres during the first phase of transformation, especially in rural areas. It can be assumed that retrenchment strategies of this type contributed to the relatively low level of indebtedness of shrinking municipalities in Poland (Rademacher 2007; Sackmann 2010). Later, in the posttransformation period, low numbers of children were offset by the introduction of a compulsory year of pre-schooling, and the system of general schools was even expanded (Kopycka 2013). In West Germany, attempts at the federal state level to modernise the traditionally conservative German welfare regime have recently led to extending childcare to children younger than 3 , thus offsetting the effect of lower numbers of children aged 3 to 6 years in the general population (Bart/2011b). Hence, low inclusiveness makes it less probable that fertility decline results in overcapacities only if normative aspirations rise at the same time - thus offsetting decline through rising participation rates. This is why in shrinking West German rural areas the level of childcare infrastructure is perceived as satisfactory while their East German counterparts interpret a similar situation as a deterioration of service provision (Steinführer et al. 2012). In higher education, rising participation rates can be interpreted as coming closer to the ideal of universal higher education. An unintended consequence of this politically desirable outcome will be that higher education will become more responsive to demographic change. Demographic decline is already a serious challenge for (private) higher education institutions in countries such as Japan or South Korea (Yonezawa/Kim 2008). There, internationalisation is discussed as the primary strategy for coping with decline. If we consider that such a strategy theoretically requires quite a high level of commodification (Sackmann 2007), normative questions about tuition fees could become more prominent. 
Internal (hierarchical and horizontal) differentiation loosens the connection between demographic trends and education supply. The present article shows that integrated secondary schools were more affected by demographic decline than advanced-track schools. This uneven demographic responsiveness points to the hierarchical differentiation of secondary schools in Germany. Similarly, demographic decline has led the structurally more fragmented general school system in West Germany to come under pressure toward dedifferentiation from the lower end of this hierarchy (Bart/ 2012b). In the 1980s, when the 1970s decline in fertility in West Germany reached the education system, this demographic pressure on enrolment was temporarily relieved through immigration, on the one hand, and through a loosening of administrative thresholds for minimum school size, on the other (Trotha 1981). Today, integrative types of schools are increasingly emerging as a solution to declining enrolment (Bart/ 2012b). As far as horizontal differentiation is concerned, low differentiation such as in primary schools allows for fairly decentralised service provision. However, this low differentiation usually means fairly small infrastructure units, which makes them prone to closure (for accordant expectations about the future in the Netherlands, see Haartsen/van Wissen 2012). Whereas special education schools have a similar number of pupils to primary schools, they have proved to be highly resilient in the face of demographic decline. Their relatively stable number points to an increased participation rate, which is especially high in Saxony-Anhalt compared to other German states. Hence, both school types raise normative questions in times of demographic decline. Shall these small schools remain open? In a comparison of the 16 German states, only one (Thuringia) had higher expenditures per pupil than Saxony-Anhalt (Statistisches Bundesamt 2010: 47). Recently, the government of Saxony-Anhalt announced the anticipated closure of 75 small primary schools that do not currently reach the administrative minimum threshold of pupils for this school type (Staatskanzlei Sachsen-Anhalt 12.02.2013). And yet, it could be argued that the fairly decentralised structure of primary schools perhaps contributed to the good results that pupils from Saxony-Anhalt achieved in a comparative study across the German states (Stanat 2012). In contrast to the apparently good results of primary schools, the relatively high expense of instructing pupils with special needs in separate schools (Preuss-Lausitz 2009) does not seem to pay off socially. In Saxony-Anhalt, 10.7 percent of total enrolment dropped out of school without a degree in 2009. Around three-quarters of those dropouts originated from special education schools. Only the state of Mecklenburg-Western Pomerania had a higher dropout rate in 2009 (12.4 percent) - and a similar participation rate in special education schools (my own calculations based on [KMK n.d.: 332-333]). In light of current discussions about a more inclusive and more efficient school system, the relative stability of the fairly expensive segregated schooling of children and youths with special needs in the face of demographic decline is an ambivalent success story. In larger organisational units declining cohort sizes exert pressure towards internal horizontal dedifferentiation. Recently, for example, vocational schools in Saxony-Anhalt began to experiment with mixed classes for apprentices of different vocations (Laag 2010). 
The level of commodification in the East German educational landscape was lower in the early 1990s than it is today. The share of private not-for-profit providers of educational infrastructure increased remarkably in early childhood, vocational, and general education. While quite a high involvement of private actors in early childhood and vocational education is common in West Germany, the same cannot be said of general education schools. Despite privatisation being still at a relatively low level in Germany, it is noteworthy that increases in private (primary) schools have been preceded by closures of public schools due to demographic decline, as other studies show (Kühne/Kann 2012). Beyond that, demographic decline seems to reinforce traditional means of rationalisation in the public sector such as calculation in kind (Bart/ 2011a), retrenchment measures, and flexible working contracts (especially in higher education). This corresponds to a reform pattern of the public sector, identified mainly in continental Europe, in which the state remains a key actor in society, normatively and empirically, and marketisation plays a rather limited role (Pollitt/Bouckaert 2011).

To sum up the analytical results of this empirical study, the following revised set of variables seems to be important for systematically investigating the demographic responsiveness of the education system (Fig. 5).

Demographic decline calls for an economisation of education infrastructure; yet migration (for education reasons) might alleviate part of this pressure. The guiding ideas of education policy, whether rooted in political or in professional reasoning, usually work against an economisation of education infrastructure. Furthermore, the demographic responsiveness of supply structures is less pronounced at education levels that display a greater degree of hierarchical or horizontal differentiation (e.g., secondary schools) compared to more inclusive sectors of the education system (e.g., primary schools). Another intervening effect seems to be related to the size of educational establishments: larger units have more potential for flexible responses to declining demand; however, this variable was not investigated systematically enough in the present paper. On the other hand, highly inclusive and highly commodified levels of education are more responsive to demographic decline than those levels with low participation and completely decommodified public supply structures. However, independent of demographic change and educational governance structures, pressure to economise the regional education system might originate in poor economic conditions in a given region. The latter becomes especially obvious when the current discussion in Saxony-Anhalt about cutbacks in higher education is considered. Here demography is used as a legitimising frame for unpopular (and maybe unwise [Ziegele/Berthold 2013]) political decisions. Hence, the demographic responsiveness of the education system is codetermined by other variables, above all by educational governance structures and the economic conditions in the region. Some of these variables hamper and others enhance economisation tendencies in education due to demographic decline. 
Fig. 5: Relevant variables determining the economisation of regional education systems in the face of demographic decline

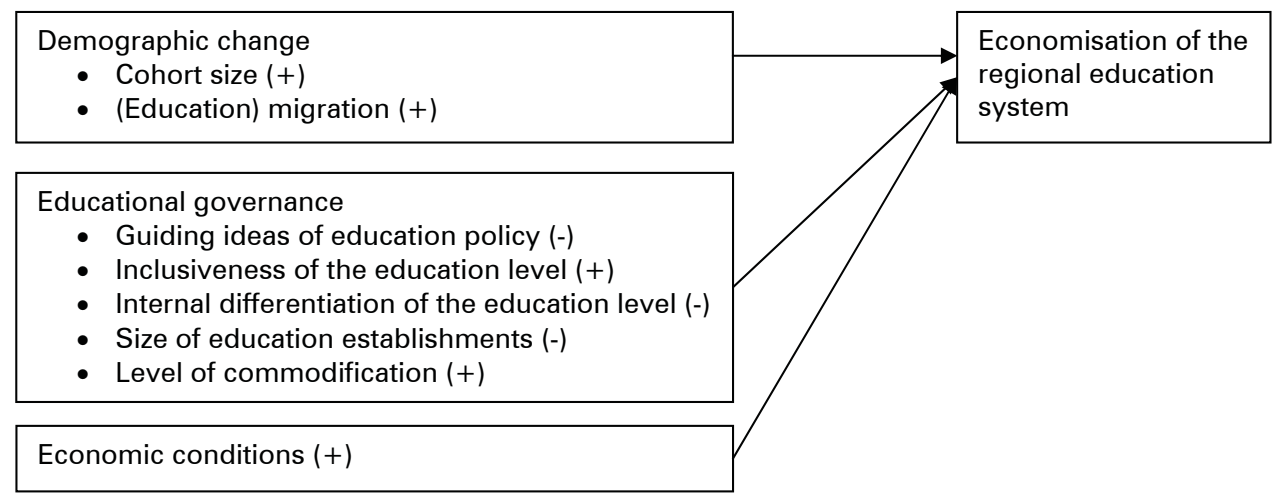

Source: own design

\section{Acknowledgements}

The present article was realised as part of the project "Governance of education systems in shrinking regions" funded by the state of Saxony-Anhalt (FKZ: 5207AD0609M). I am grateful for the valuable comments of Paul Gans, Reinhold Sackmann, and two anonymous referees. I also thank Peter Harding for his support with the data on vocational schools.

\section{References}

A Aberg-Bengtsson, Lisbeth 2009: The smaller the better? A review of research on small rural schools in Sweden. In: International Journal of Educational Research 48,2: 100-108 [doi: 10.1016/j.ijer.2009.02.007].

Andrews, Matthew; Duncombe, William; Yinger, John 2002: Revisiting economies of size in American education: are we any closer to a consensus? In: Economics of education review 21,3: 245-262 [doi: 10.1016/S0272-7757(01)00006-1].

Auth, Diana; Holland-Cunz, Barbara (Eds.) 2007: Grenzen der Bevölkerungspolitik. Strategien und Diskurse demographischer Steuerung. Opladen: Verlag Barbara Budrich.

Autorengruppe Bildungsberichterstattung (Eds.) 2010: Bildung in Deutschland 2010. Ein indikatorengestützter Bericht mit einer Analyse zu Perspektiven des Bildungswesens im demografischen Wandel. Im Auftrag der Ständigen Konferenz der Kultusminister der Länder in der Bundesrepublik Deutschland und des Bundesministeriums für Bildung und Forschung. Bielefeld.

Baker, David; Köhler, Helmut; Stock, Manfred 2007: Socialist Ideology and the Contraction of Higher Education: Institutional Consequences of State Manpower and Education Planning in the Former East Germany. In: Comparative education review 51,3: 353-378 [doi: 10.1086/518481]. 
Barker, Roger G.; Gump, Paul V. 1964: Big school, small school. High school size and student behavior. Stanford/California: University Press.

Bartl, Walter 2011a: Demografisierung der Kommunalpolitik? Bevölkerung als Schema kommunaler Selbstverwaltung. In: Soziale Welt 62,4: 351-369 [doi: 10.5771/ 0038-6073-2011-4-351].

Bartl, Walter 2011b: Personalpolitik in schrumpfenden Kommunen. Ostdeutschland, Westdeutschland und Polen im Vergleich. Wiesbaden: VS Verlag für Sozialwissenschaften [doi: 10.1007/978-3-531-93078-7].

Bartl, Walter 2012a: Die demografische Reagibilität regionaler Hochschulsysteme. Eine Sekundärdatenanalyse am Beispiel von Sachsen-Anhalt. In: Beiträge zur Hochschulforschung 34,4: 78-106.

Bartl, Walter 2012b: Entdifferenzierung der regionalen Schulstruktur in Deutschland durch demografischen Wandel? Martin-Luther-Universität, Institut für Soziologie. Der Hallesche Graureiher, 2012-3. Halle (Saale).

Basu, Ranu 2007: Negotiating Acts of Citizenship in an Era of Neoliberal Reform: The Game of School Closures. In: International Journal of Urban and Regional Research 31,1: 109-127 [doi: 10.1111/j.1468-2427.2007.00709.x].

Bathgate, Jeanne M. 2007: School closure. A case study. PhD thesis. University of Sydney. Sydney [http://ses.library.usyd.edu.au/bitstream/2123/1777/2/Bathgate02Whole. pdf, 04.03.2013].

Baum, Britta; Seitz, Helmut 2003: Demographischer Wandel und Bildungsausgaben: Empirische Evidenz für die westdeutschen Länder. In: Vierteljahreshefte zur Wirtschaftsforschung 72,2: 205-219 [doi: 10.3790/vjh.72.2.205].

Billger, Sherrilyn M. 2010: Demographics, fiscal health, and school quality. Shedding light on school closure decisions. IZA Discussion paper series, 4739. Bonn.

$B M B F$ (Eds.) 2011: Berufsbildungsbericht 2011. Bundesministerium für Bildung und Forschung. Berlin.

Bondi, Liz 1987: School closures and local politics: the negotiation of primary school rationalization in Manchester. In: Political Geography Quarterly 6,3: 203-224 [doi: 10.1016/S0260-9827(87)80001-0].

Bondi, Liz 1989: Selecting schools for closure: theory and practice in 'rational' planning In: Journal of Education Policy 4,2: 85-102 [doi: 10.1080/0268093890040201].

Bönisch, Peter; Tagge, Sven 2012: The optimal size of German child care centers and the impact of regulation. Estimating the cost function of a regulated multi-product firm. In: Jahrbücher für Nationalökonomie und Statistik 232,5: 545-566.

Borge, Lars-Erik; Rattsø, Jørn 1995: Demographic Shift, Relative Costs and the Allocation of Local Public Consumption in Norway. In: Regional Science and Urban Economics 25,6: 705-726.

Borge, Lars-Erik; Ratts $\emptyset$, Jørn 2008: Young and old competing for public welfare services. CESifo working paper, 2223. München.

Busemeyer, Marius R. 2007: Determinants of public education spending in 21 OECD democracies, 1980-2001. In: Journal of European Public Policy 14,4: 582-610 [doi: 10.1080/13501760701314417].

Busemeyer, Marius R.; Goerres, Achim; Weschle, Simon 2008: Demands for Redistributive Policies in an Era of Demographic Aging: The Rival Pressures from Age and Class in 15 OECD Countries. MPIfG Discussion Paper, 08/3. Köln. 
Cattaneo, M. Alejandra; Wolter, Stefan C. 2007: Are the elderly a threat to educational expenditures? CESifo working paper, 2089. Munich.

CEDEFOP 2009: Implications of demographic change for vocational education and training in the EU. Luxembourg: Office for Official Publications of the European Communities [doi: 10.2801/31146].

Clark, Christopher D. et al. 2009: Willingness to Fund Public Education in a Rural, Retirement Destination County. In: Journal of Research in Rural Education 24,6: 1-16.

Cortina, Kai S. et al. (Eds.) 2008: Das Bildungswesen in der Bundesrepublik Deutschland. Reinbek bei Hamburg: Rowohlt Taschenbuch Verlag [doi: 10.978.3499/623394].

Derenbach, Rolf; Gatzweiler, Hans-Peter 1988: Sicherung der Schulstandorte unter veränderten Rahmenbedingungen - eine gemeinsame Aufgabe von Raumordnungsund Bildungspolitik. In: Informationen zur Raumentwicklung 7: 407-410.

Dietze, Torsten 2011: Sonderpädagogische Förderung in Zahlen - Ergebnisse der Schulstatistik 2009/10 mit einem Schwerpunkt auf der Analyse regionaler Disparitäten. In: Inklusion online 5,2: [http://www.inklusion-online.net/index.php/inklusion/article/ view/105/106, 01.03.2013]

Döring, Peter A. (Eds.) 1977: Große Schulen oder kleine Schulen? Zur Dimensionierung von Bildungseinrichtungen. Erziehung in Wissenschaft und Praxis 27. München: Piper.

Engberg, John et al. 2012: Closing schools in a shrinking district: Do student outcomes depend on which schools are closed? In: Journal of Urban Economics 71,2: 189-204 [doi: 10.1016/j.jue.2011.10.001].

European Commission/Economic Policy Committee 2009: The 2009 ageing report: economic and budgetary projections for the EU-27 Member States (2008-2060). Luxembourg: Office for Official Publications of the European Communities [doi: 10.2765/80301].

Fernandez, Raquel; Rogerson, Richard 2001: The Determinants of Public Education Expenditures: Longer-Run Evidence from the States. In: Journal of Education Finance 27: $567-584$

Fickermann, Detlef; Schulzeck, Ursula; Weishaupt, Horst 2000: Zur Effizienz regionaler Schulstandortsysteme am Beispiel von Mecklenburg-Vorpommern. In: Weiß, Manfred; Weishaupt, Horst (Eds.): Bildungsökonomie und Neue Steuerung. Frankfurt am Main: Lang: 169-202.

Fickermann, Detlef; Weishaupt, Horst; Zedler, Peter 1998: Kleine Grundschulen in Deutschland: Rückblick und Ausblick. In: Fickermann, Detlef (Eds.): Kleine Grundschulen in Europa. Berichte aus elf europäischen Ländern. Weinheim: Deutscher Studienverlag: 7-34.

Figlio, David N.; Fletcher, Deborah 2012: Suburbanization, demographic change and the consequences for school finance. In: Journal of public economics 96,11-12: 1144-1153 [doi: 10.1016/j.jpubeco.2011.07.007].

Frank, Keno 2011: Schulentwicklungsplanung im demografischen Wandel. Am Beispiel der Kreise Dithmarschen und Steinburg. Universität Kiel. Kieler Arbeitspapiere zur Landeskunde und Raumordnung 52. Kiel.

Füssel, Hans-Peter et al. 2010: Der institutionelle Kontext von Übergangsentscheidungen: Rechtliche Regelungen und die Schulformwahl am Ende der Grundschulzeit. In: Maaz, Kai et al. (Eds.): Der Übergang von der Grundschule in die weiterführende Schule. Leistungsgerechtigkeit und regionale, soziale und ethnisch-kulturelle Disparitäten. Berlin: BMBF, 87-106. 
Gans, Paul; Schmitz-Veltin, Ansgar (Eds.) 2006: Demographische Trends in Deutschland. Folgen für Städte und Regionen. Räumliche Konsequenzen des demographischen Wandels 6. Hannover: Akademie für Raumforschung und Landesplanung (ARL).

Gemeinsame Wissenschaftskonferenz 2012: Hochschulpakt 2020. Bericht zur Umsetzung in den Jahren 2007 bis 2010 und Jahresbericht 2010. Materialien der GWK 27. [http://www.gwk-bonn.de/fileadmin/Papers/GWK-Heft-27-Hochschulpakt-Umsetzung-2010.pdf, 04.03.2013].

Gradstein, Mark; Kaganovich, Michae/ 2004: Aging population and education finance. In: Journal of public economics 88,12: 2469-2486 [doi: 10.1016/S0047-2727(03)00065-3].

Grob, Ueli; Wolter, Udo 2005: Demographic Change and Public Education Spending. A Conflict between Young and Old? CESifo working paper,1555. Munich.

Grünert, Holle 2010: Das Berufsbildungssystem in Ostdeutschland - eine Lerngelegenheit angesichts neuer Herausforderungen? In: Die deutsche Schule 102,3: 237-255.

Grünert, Holle; Lutz, Burkart; Wiekert, Ingo 2006: Zukunftsperspektiven der Berufsausbildung in den neuen Ländern und die Rolle der Bildungsträger. Abschlussbericht des Projekts. Zentrum für Sozialforschung Halle (Saale).

Haartsen, Tialda; van Wissen, Leo 2012: Causes and Consequences of Regional Population Decline for Primary Schools. In: Tijdschrift voor economische en sociale geografie 103,4: 487-496 [doi: 10.1111/j.1467-9663.2012.00736.x].

Hank, Karsten; Tillmann, Katja; Wagner, Gert G. 2001: Außerhäusliche Kinderbetreuung in Ostdeutschland vor und nach der Wiedervereinigung. Ein Vergleich mit Westdeutschland in den Jahren 1990 - 1999. Max-Planck-Institut für demografische Forschung. MPIDR Working Paper 2001-003. Rostock.

Hannemann, Christine 2004: Marginalisierte Städte. Probleme, Differenzierungen und Chancen ostdeutscher Kleinstädte im Schrumpfungsprozess. Berlin: BWV

Harris, Amy R.; Evans, William N.; Schwab, Robert M. 2001: Education spending in an aging America. In: Journal of public economics 81,3: 449-472 [doi: 10.1016/S00472727(00)00133-X].

Harrison, Diane A.; Busher, Hugh 1995: Small schools, big ideas: Primary education in rural areas. In: British journal of educational studies 43,4: 384-397 [doi: 10.1080/00071005.1995.9974046].

Hering, Sabine (Eds.) 2009: Social care under state socialism (1945-1989). Ambitions, ambiguities, and mismanagement. Opladen: Barbara Budrich Publishers.

Hippach-Schneider, Ute; Hensen, Kristina Alice; Schober, Karen (Eds.) 2012: VET in Europe - Country Report Germany. 2. revised edition. Bundesinstitut für Berufsbildung (BIBB). Bonn.

Hyll, Walter; Schneider, Lutz 2012: Grundschulschließungen als Katalysator von Wanderungsbewegungen? In: Friedrich, Klaus; Pasternack, Peer (Eds.): Demografischer Wandel als Querschnittsaufgabe. Halle (Saale): Universitätsverlag Halle-Wittenberg: 235-251.

Itō, Takatoshi; Rose, Andrew (Eds.) 2010: The economic consequences of demographic change in East Asia. Chicago: University of Chicago Press [doi: 10.7208/chicago/9780226386881.001.0001].

Kalaoja, Esko; Pietarinen, Janne 2009: Small rural primary schools in Finland: A pedagogically valuable part of the school network. In: International Journal of Educational Research 48,2: 109-116 [doi: 10.1016/j.ijer.2009.02.003]. 
Kearns, Andrew 2011: The Wilingboro NJ School District and the Politics of Decline 1970-1979. Rutgers State University of New Jersey. Graduate School of Education. New Brunswick.

Kempkes, Gerhard 2009: Public Education Spending in the German Länder. Adjustment to Demographic Shocks, Politics, and Cost Efficiency. Dissertation. Technische Universität. Fakultät Wirtschaftswissenschaften. Dresden [http://www.qucosa.de/filead$\mathrm{min} /$ data/qucosa/documents/2656/Diss-KEMPKES-Jan2010.pdf, 04.03.2013].

Kenny, Lawrence W.; Schmidt, Amy B. 1994: The decline in the number of school districts in the U.S.: 1950-1980. In: Public choice 79,1-2: 1-18 [doi: 10.1007/BF01047915].

KMK (Eds.) w.y.: Schüler, Klassen, Lehrer und Absolventen der Schulen 2000 bis 2009. Sekretariat der Ständigen Konferenz der Kultusminister der Länder in der Bundesrepublik Deutschland. Statistische Veröffentlichungen der Kultusministerkonferenz 190. Berlin [http://www.kmk.org/fileadmin/pdf/Statistik/Dok_190_SKL.pdf, 04.03.2013].

Kohler, Hans-Peter; Billari, Francesco C.; Ortega, José A. 2002: The Emergence of Lowest-Low Fertility in Europe During the 1990s. In: Population and Development Review 28,4: 641-680 [doi: 10.1111/j.1728-4457.2002.00641.x].

Kopycka, Katarzyna 2013: Demografischer Wandel, Bildungspolitik und Lehrerbeschäftigung. Das Beispiel Polen. Wiesbaden: Springer VS [doi: 10.1007/978-3-531-19399-1].

Kramer, Caroline 1997: Schulpolitische Leitbilder und persönliche Einstellungen zu kleinen Grundschulen. Erfahrungen aus Vorarlberg und Baden-Württemberg. In: Sandfuchs, Uwe (Eds.): Kleine Grundschule und jahrgangsübergreifendes Lernen. Schülerrückgang als pädagogische Herausforderung. Bad Heilbrunn/Obb: Klinkhardt: 77-93.

Kramer, Caroline; Nutz, Manfred 2006: Räumliche Auswirkungen des demographischen Wandels auf das Bildungs- und Erziehungswesen. In: Gans, Paul; Schmitz-Veltin, Ansgar (Eds.): Demographische Trends in Deutschland. Folgen für Städte und Regionen. Räumliche Konsequenzen des demographischen Wandels 6. Hannover: Akademie für Raumforschung und Landesplanung (ARL): 192-220.

Kučerová, Silvie; Kučera, Zdeněk 2012: Changes in the Spatial Distribution of Elementary Schools and Their Impact on Rural Communities in Czechia in the Second Half of the 20th Century. In: Journal of Research in Rural Education 27,11: 1-17.

Kühne, Stefan; Kann, Caroline 2012: Private (Grund-)Schulen als blinder Fleck der öffentlichen Daseinsvorsorge? Regionale Analysen zu Entwicklungen in der deutschen Privatschullandschaft. In: Die deutsche Schule 104,3: 256-279.

Kultusministerium Sachsen-Anhalt (Eds.) 2010: Bildungsbericht 2010 Sachsen-Anhalt. Magdeburg.

Laag, Niels 2010: Mischklassen im Rahmen der Schulentwicklungsplanung für berufsbildende Schulen - Curriculare und schulorganisatorische Ansätze sowie Akzeptanzbedingungen. Masterarbeit. Universität Magdeburg. Institut für Berufs- und Betriebspädagogik. Magdeburg.

Ladd, Helen F.; Murray, Sheila E. 2001: Intergenerational conflict reconsidered: county demographic structure and the demand for public education. In: Economics of education review 20,4: 343-357 [doi: 10.1016/s0272-7757(00)00058-3].

Landtag Sachsen-Anhalt 31.08.1993: Gesetz über die Horte an Grundschulen in SachsenAnhalt. Hortgesetz. In: Gesetz- und Verordnungsblatt Sachsen-Anhalt 4: 523-525.

Landtag Sachsen-Anhalt 18.07.1996: Gesetz zur Änderung des Gesetzes zur Förderung von Kindern in Tageseinrichtungen. In: Gesetz- und Verordnungsblatt Sachsen-Anhalt 7: 224-230. 
Landtag Sachsen-Anhalt 2004: Gesetz zur Förderung und Betreuung von Kindern in Tageseinrichtungen und Tagespflege des Landes Sachsen-Anhalt vom 5. März 2003. Kinderfördergesetz (KiFöG). [http://www.sachsen-anhalt.de/LPSA/fileadmin/Files/ gesetz.pdf, 28.02.2013].

Landtag Sachsen-Anhalt 2005: Schulgesetz des Landes Sachsen-Anhalt vom 12. August 2005. [http://www.mk-intern.bildung-Isa.de/Bildung/ge-schulgesetz_2009.pdf, 04.03.2013].

Lechner, Michael 2001: The Empirical Analysis of East German Fertility after Unification: An Update. In: European Journal of Population 17,1: 61-74 [doi: 10.1023/A:1010792230291].

Lehmann, Rainer H. 1994: Germany: System of Education. In: Husén, Torsten; Postlethwaite, T. Neville (Eds.): The International encyclopedia of education. Volume 5. Oxford: Pergamon: 2470-2480.

Lepsius, Rainer M. 1995: Institutionenanalyse und Insititutionenpolitik. In: Nedelmann, Birgitta (Eds.): Politische Institutionen im Wandel. Sonderheft 35 der Kölner Zeitschrift für Soziologie und Sozialpsychologie. Opladen: Westdeutscher Verlag: 392-403.

Mai, Ralf 2004: Abwanderung aus Ostdeutschland: Strukturen und Milieus der Altersselektivität und ihre regionalpolitische Bedeutung. Frankfurt am Main: Peter Lang.

Martens, Kerstin; Rusconi, Alessandra; Leuze, Kathrin (Eds.) 2007: New arenas of education governance. The impact of international organizations and markets on educational policy making. Basingstoke: Palgrave Macmillan.

Mayer, Karl U. 2008: Das Hochschulwesen. In: Cortina, Kai S. et al. (Eds.): Das Bildungswesen in der Bundesrepublik Deutschland. Reinbek bei Hamburg: Rowohlt Taschenbuch Verlag: 599-645.

Meusburger, Peter 1998: Bildungsgeographie. Wissen und Ausbildung in der räumlichen Dimension. Heidelberg: Spektrum.

Meusburger, Peter 2005: The future of elementary schools in Alpine Regions. In: La revue de géographie alpine 93,2: 85-194 [doi: 10.3406/rga.2005.2348].

Meyer, John W.; Ramirez, Francisco O.; Soysal, Yasemin N. 1992: World Expansion of Mass Education, 1870-1980. In: Sociology of Education 65,2: 128-149 [doi: 10.2307/2112679].

Nikolai, Rita; Ebner, Christian 2012: The Link between Vocational Training and Higher Education in Switzerland, Austria, and Germany. In: Busemeyer, Marius R.; Trampusch, Christine (Eds.): The political economy of collective skill formation. Oxford: Oxford Univ. Press: 234-258 [doi: 10.1093/acprof:oso/9780199599431.003.0009].

Nitta, Keith A.; Holley, Marc J.; Wrobel, Sharon L. 2010: A Phenomenological Study of Rural School Consolidation. In: Journal of Research in Rural Education 25,2: 1-19.

Oberndorfer, Ulrich; Steiner, Viktor 2006: Generationen- oder Parteienkonflikt? Eine empirische Analyse der deutschen Hochschulausgaben. Zentrum für Europäische Wirtschaftsforschung (ZEW). ZEW Discussion Paper 06-052. Mannheim.

OECD (Eds.) 2008: Higher education to 2030. Volume 1: Demography. Paris: OECD Publishing [doi: 10.1787/9789264040663-en].

OECD 2011: Education at a glance, 2011. OECD indicators. Paris: OECD Publishing [doi: 10.1787/eag-2011-en].

Ohtake, Fumio; Sano, Shinpei 2010: The Effects of Demographic Change on Public Education in Japan. In: Itō, Takatoshi; Rose, Andrew (Eds.): The economic consequences of demographic change in East Asia. Chicago: University of Chicago Press: 193-219 [doi: 10.7208/chicago/9780226386881.003.0007]. 
Pollitt, Christopher; Bouckaert, Geert 2011: Public management reform. A comparative analysis. New public management, governance, and the Neo-Weberian state. Oxford: Oxford University Press.

Post, David; Stambach, Amy 1999: District Consolidation and Rural School Closure: E Pluribus Unum? In: Journal of Research in Rural Education 15,2: 106-117.

Poterba, James M. 1997: Demographic Structure and the Political Economy of Public Education. In: Journal of Policy Analysis and Management 16,1: 48-66.

Powell, Justin J.W. 2011: Barriers to inclusion. Special education in the United States and Germany. Boulder, CO: Paradigm.

Preston, Samuel H. 1984: Children and the Elderly: Divergent Paths for America's Dependents. In: Demography 21,4: 435-457 [doi: 10.2307/2060909].

Preuss-Lausitz, Ulf 2009: Untersuchungen zur Finanzierung sonderpädagogischer Förderung in integrativen und separaten Schulen. In: Eberwein, Hans; Knauer, Sabine (Eds.): Handbuch Integrationspädagogik: Kinder mit und ohne Beeinträchtigung lernen gemeinsam. Beltz Pädagogik. Weinheim: Beltz: 514-524.

Rademacher, Christian 2007: Die kommunale Bewaltigung demographischer Herausforderungen: Deskriptive Ergebnisse im deutsch-polnischen Vergleich. In: Sackmann, Reinhold et al. (Eds.): Strategien zur Bewältigung des demografischen Wandels im öffentlichen Sektor. Mitteilungen des SFB 580 24. Halle: SFB 580: 12-46.

Rakhkochkine, Anatoli 2007: Zusammenlegungen von Schulen in Irland, Russland und den Niederlanden. In: Zeitschrift für Bildungsverwaltung 1: 49-61.

Ratts $\emptyset$, Jørn; Sørensen, Rune J. 2010: Grey power and public budgets: Family altruism helps children, but not the elderly. In: European Journal of Political Economy 26,2: 222-234 [doi: 10.1016/j.ejpoleco.2009.11.010].

Reisz, Robert; Stock, Manfred 2007: Theorie der Weltgesellschaft und statistische Modelle im soziologischen Neoinstitutionalismus. In: Zeitschrift für Soziologie 36,2: 82-99.

Roloff, Juliane 2007: Familienpolitik und Geburtenentwicklung unter besonderer Berücksichtigung der Situation in der ehemaligen DDR. In: Auth, Diana; Holland-Cunz, Barbara (Eds.): Grenzen der Bevölkerungspolitik. Strategien und Diskurse demographischer Steuerung. Opladen: Verlag Barbara Budrich: 127-143.

Sackmann, Reinhold 2000: Transformation, Arbeitsmarkt und Lebenslauf. In: Sackmann, Reinhold; Weymann, Ansgar; Wingens, Matthias (Eds.): Die Generation der Wende: Berufs- und Lebensverläufe im sozialen Wandel. Wiesbaden: Westdeutscher Verlag: 41-56 [doi: 10.1007/978-3-322-83354-9_3].

Sackmann, Reinhold 2004: Internationalisierung von Bildungsmärkten? Empirische Daten zur Kommerzialisierung von Bildung in Deutschland und den USA. In: Beiträge zur Hochschulforschung 26, 4: 62-92.

Sackmann, Reinhold 2007: Internationalization of markets for education? New actors within nations and increasing flows between nations. In: Martens, Kerstin; Rusconi, Alessandra; Leuze, Kathrin (Eds.): New arenas of education governance. The impact of international organizations and markets on educational policy making. Basingstoke: Palgrave Macmillan: 155-175.

Sackmann, Reinhold 2010: Institutional Responses to Social Change in Comparative Perspective: Germany and Poland. In: Silbereisen, Rainer K.; Chen, Xinyin (Eds.): Social Change and Human Development: Concepts and Results. London: Sage: 167-189. 
Schimank, Uwe; Volkmann, Ute 2012: Economizing and Marketization in a Functionally Differentiated Capitalist Society - A Theoretical Conceptualization. Paper for the conference: "The Marketization of Society: Economizing the Non-Economic", University of Bremen, June 1-2, 2012. [http://www.mpifg.de/projects/marketization/downloads/ Schimank_Volkmann.pdf, 04.03.2013].

Schofer, Evan; Meyer, John W. 2005: The Worldwide Expansion of Higher Education in the Twentieth Century. In: American Sociological Review 70,6: 898-920 [doi: 10.1177/000312240507000602].

Schultz, Theodore P. 1988: Expansion of public school expenditures and enrollments Intercountry evidence on the effects of income, prices, and population growth. In: Economics of education review 7,2: 167-183.

Seitz, Helmut 2008: Die Demographieabhängigkeit der Ausgaben und Einnahmen der öffentlichen Haushalte. Eine empirische Analyse unter Berücksichtigung der föderalen Verflechtungen. Bertelsmann Stiftung. Gütersloh.

Sell, Randall S.; Leistritz, F. Larry 1997: Socioeconomic impacts of school consolidation on host and vacated communities. In: Journal of the Community Development Society 28,2: 186-205 [doi: 10.1080/15575339709489782].

Sher, Jonathan P. 1981: Education in the Countryside: Overview of Conditions and some Conclusions. In: Sher, Jonathan P. (Eds.): Rural education in urbanized nations. Issues and innovations. Boulder, CO: Westview Press: 21-90.

Staatskanzlei Sachsen-Anhalt 12.02.2013: Kultusminister stellt Eckwerte der neuen Verordnung zur Schulentwicklungsplanung vor. Pressemitteilung Nr.: 078/2013. Magdeburg [http://www.presse.sachsen-anhalt.de/index.php?cmd=get\&id=858521\& identifier $=$ eced798d6eba289cc17bb131b2af810e, 27.02.2013].

Stanat, Petra (Eds.) 2012: Kompetenzen von Schülerinnen und Schülern am Ende der vierten Jahrgangsstufe in den Fächern Deutsch und Mathematik. Ergebnisse des IQBLändervergleichs 2011. Münster: Waxmann.

Statistisches Bundesamt 2004: Kindertagesbetreuung in Deutschland: Einrichtungen, Plätze, Personal, Kosten 1990 bis 2002. Statistisches Bundesamt: Wiesbaden.

Statistisches Bundesamt 2010: Bildungsfinanzbericht 2010. Im Auftrag des Bundesministeriums für Bildung und Forschung und der Ständigen Konferenz der Kultusminister der Länder in der Bundesrepublik Deutschland. Wiesbaden.

Statistisches Bundesamt 2012: Bevölkerung: Bundesländer, Stichtag. Tabelle: Code 12411-0009. [https://www-genesis.destatis.de/genesis/online, 01.09.2012].

Statistisches Landesamt Sachsen 2006: Berufsbildende Schulen im Freistaat Sachsen. Schuljahr 2005/06. Kamenz.

Steinführer, Annett; Küpper, Patrick; Tautz, Alexandra 2012: Strategien der Daseinsvorsorge unter den Bedingungen von Alterung und Bevölkerungsrückgang: Fallstudien im Harz. Johann Heinrich von Thünen-Institut. Landbauforschung Sonderheft 367. Braunschweig.

Stinchcombe, Jean 1984: Response to declining enrollment. School-closing in suburbia. Lanham: University Press of America.

Thelen, Kathleen; Busemeyer, Marius R. 2012: Institutional Change in German Vocational Training. From Collectivism toward Segmentalism. In: Busemeyer, Marius R.; Trampusch, Christine (Eds.): The political economy of collective skill formation. Oxford: Oxford University Press: 68-100 [doi: 10.1093/acprof:oso/9780199599431.003.0003].

Trotha, Thilo v. 1981: Sicherung einer wohnungsnahen Schulversorgung durch die Länder. In: Informationen zur Raumentwicklung 9: 655-661. 
Turner, Ralph H. 1960: Sponsored and Contest Mobility and the School System. In: American Sociological Review 25: 855-867.

Vincent-Lancrin, Stéphan 2008: What is the Impact of Demography on Higher Education Systems? A Forward-looking Approach for OECD Countries. In: OECD (Eds.): Higher education to 2030. Volume 1: Demography. Paris: OECD Publishing: 41-103 [doi: 10.1787/9789264040663-3-en].

Weishaupt, Horst 2006: Veränderungen im elementaren und sekundären Bildungsbereich durch demographischen Wandel. In: Statistisches Bundesamt (Eds.): Demographischer Wandel - Auswirkungen auf das Bildungssystem. Beiträge zum wissenschaftlichen Kolloquium am 18. und 19. November 2004 in Wiesbaden. Statistik und Wissenschaft 6. Wiesbaden: 26-44.

Weishaupt, Horst; Weiß, Manfred 1988: Bildungsbudget und interne Mittelallokation. In: Zeitschrift für Pädagogik 34: 535-553.

Weiß, Manfred; Weishaupt, Horst (Eds.) 2000: Bildungsökonomie und Neue Steuerung. Frankfurt am Main: Lang.

Wiborg, Susanne 2010: Why is there no comprehensive education in Germany? A historical explanation. In: History of Education 39,4: 539-556 [doi: 10.1080/00467601003685733].

Windzio, Michael; Sackmann, Reinhold; Martens, Kerstin 2005: Types of governance in education. A quantitative analysis. Universität Bremen. TranState working papers 25. Bremen.

Winter, Martin 2011: Studium und Studienreform im Vergleich der Bundesländer. Statistische Entwicklungen, Landeshochschulgesetze, Zielvereinbarungen und ministerielle Vorgaben. In: Pasternack, Peer (Eds.): Hochschulen nach der Föderalismusreform. Leipzig: Akademische Verlagsanstalt: 215-280.

Witte, Johanna; Stuckrad, Thimo von 2007: Kapazitätsplanung in gestuften Studienstrukturen. Vergleichende Analyse des Vorgehens in 16 Bundesländern. Centrum für Hochschulentwicklung (CHE - Centrum für Hochschulentwicklung). Arbeitspapier 89. Gütersloh.

Witten, Karen et al. 2003: Educational restructuring from a community viewpoint: a case study of school closure from Invercargill, New Zealand. In: Environment and Planning C: Government and Policy 21,2: 203-223 [doi: 10.1068/c05r].

World Bank 2006: World Development Report 2007. Washington, D.C.: World Bank Publications.

Yonezawa, Akiyoshi; Kim, Terri 2008: The Future of Higher Education in the Context of a Shrinking Student Population. Policy Challenges for Japan and Korea. In: OECD (Eds.): Higher education to 2030. Volume 1: Demography. Paris: OECD Publishing: 199-220.

Ziegele, Frank; Berthold, Christian 2013: Bildungschancen junger Menschen realisieren und in den Innovationsstandort Sachsen-Anhalt investieren: Hochschulsystem stärken und nicht durch Kürzungen ausbremsen! CHE (Centrum für Hochschulentwicklung). Gütersloh [http://www.che.de/downloads/Stellungnahme_Sachsen_Anhalt_1541.pdf, 27.02.2013]. 
408 - Walter Bartl

A German translation of this reviewed and author's authorised original article by the Federal Institute for Population Research is available under the title "Okonomisierung des Bildungssystems in schrumpfenden Regionen? Demografische Reagibilität von Bildungsnachfrage und -angebot auf verschiedenen Stufen des Bildungssystems", DOI 10.12765/CPOS-2013-19de or URN urn:nbn:de:bib-cpos-2013-19de8, at http://wWw.comparativepopulationstudies.de.

Date of submission: 16.10 .2012

Date of Acceptance: 21.05.2013

Dr. Walter Bartl $(\bowtie)$. Martin-Luther-Universität Halle-Wittenberg, Institut für Soziologie. Halle (Saale) Germany. E-Mail: walter.bartl@soziologie.uni-halle.de,

URL: http://www.soziologie.uni-halle.de/sozialstruktur/bartl/ 


\section{Comparative Population Studies}

WWW.comparativepopulationstudies.de

ISSN: 1869-8980 (Print) - 1869-8999 (Internet)

Published by / Herausgegeben von

Prof. Dr. Norbert F. Schneider

Federal Institute for Population Research

D-65180 Wiesbaden / Germany

Managing Editor /

Verantwortlicher Redakteur

Frank Swiaczny

Assistant Managing Editor /

Stellvertretende Redakteurin

Katrin Schiefer

Language \& Copy Editor (English) /

Lektorat \& Übersetzungen (englisch)

Amelie Franke

Copy Editor (German) /

Lektorat (deutsch)

Dr. Evelyn Grünheid

\section{Layout / Satz}

Beatriz Feiler-Fuchs

E-mail:cpos@bib.bund.de

\author{
Scientific Advisory Board / \\ Wissenschaftlicher Beirat \\ Paul Gans (Mannheim) \\ Johannes Huinink (Bremen) \\ Michaela Kreyenfeld (Rostock) \\ Marc Luy (Wien) \\ Clara H. Mulder (Groningen) \\ Notburga Ott (Bochum) \\ Peter Preisendörfer (Mainz) \\ Zsolt Spéder (Budapest)
}

\section{Board of Reviewers / Gutachterbeirat} Martin Abraham (Erlangen)

Laura Bernardi (Lausanne)

Hansjörg Bucher (Bonn)

Claudia Diehl (Konstanz)

Andreas Diekmann (Zürich)

Gabriele Doblhammer-Reiter (Rostock)

E.-Jürgen Flöthmann (Bielefeld)

Alexia Fürnkranz-Prskawetz (Wien)

Beat Fux (Salzburg)

Joshua Goldstein (Berkeley)

Karsten Hank (Köln)

Sonja Haug (Regensburg)

Aart C. Liefbroer (Den Haag)

Kurt Lüscher (Konstanz)

Dimiter Philipov (Wien)

Tomáš Sobotka (Wien)

Heike Trappe (Rostock) 